Reviews In Fisheries Science \& Aquaculture

2014, Volume 22 Issue 2 Pages 156-174

http://dx.doi.org/10.1080/23308249.2014.899557

http://archimer.ifremer.fr/doc/00222/33368/

(c) Taylor \& Francis Group, LLC

\title{
Technological Development and Fisheries Management
}

\author{
Eigaard Ole Ritzau ${ }^{1, *}$, Marchal Paul ${ }^{2}$, Gislason Henrik ${ }^{1}$, Rijnsdorp Adriaan D. ${ }^{3,4}$
}

${ }^{1}$ DTU Aqua, DK-2920 Charlottenlund, Denmark.

2 IFREMER, Channel \& North Sea Fisheries Res Unit, Boulogne, France.

3 IMARES Wageningen UR, ljmuiden, Netherlands.

${ }^{4}$ Wageningen Univ, Aquaculture \& Fisheries Grp, NL-6700 AP Wageningen, Netherlands.

* Corresponding author : Ole Ritzau Eigaard, email address : ore@aqua.dtu.dk

\begin{abstract}
:
Many marine fish stocks are overexploited and considerable overcapacity exists in fishing fleets worldwide. One of the reasons for the imbalance between resource availability and fishing capacity is technological development, which continuously increases the efficiency of the vessels-a mechanism referred to as "technological creep." We review how the introduction of new and more efficient electronic equipment, gear design, engines, deck equipment, and catch-handling procedures influences the capture efficiency (catchability) of commercial fishing vessels. On average, we estimate that catchability increases by $3.2 \%$ per year due to technological developments, an increase often ignored in fisheries management. The documentation and quantification of technological creep improves the basis for successfully integrating the effects of technological development (and catchability changes) in fisheries management regulations and policies. Ways of counteracting the undesired effects of technological creep are discussed as are the potential management benefits from improved fishing technology. Specific suggestions are given on the selection, application, and tuning of fisheries management tools that can be used to improve the balance between harvesting capacity and resource availability.
\end{abstract}

Keywords: catchability, fishing mortality, fishing power, fisheries management, fleet capacity, technological development 


\section{Introduction}

Compared to agriculture and livestock production on land, the living resources of the sea are mainly harvested on a hunting and gathering basis. Marine living resources typically move around and are difficult to locate and identify, and fishers often harvest a heterogeneous crop consisting of multiple species and age classes captured across large temporal and spatial variations in ocean productivity. The pressure exerted by fishers on fish stocks (fishing mortality) is therefore often poorly correlated to fishing effort and the resulting catch.

In the past decades the understanding of the relationship between fishing effort and fishing mortality (F) has improved, owing mainly to an increasing number of public funded research programmes intended to stimulate scientific investigations of fishing mortality dynamics. This interest for the "F-science” (Reeves et al., 2008), may have resulted from several examples of large-scale policies of fishing capacity and effort reductions having failed to meet their objectives of reducing fishing mortalities (FAO, 2012). In some cases most of the policy objectives relating to reduction in the number of vessels, in gross tonnage and in fishing effort have been met, but even so the expected reduction in fishing mortalities did not materialize (EC, 2008). This can be the result of a number of factors, including the availability of subsidies for the modernisation and renewal of the remaining fleet (Lindebo, 2005), which boosts the technologically driven increases in catchability (technical efficiency) of the remaining vessels, thereby undermining the achieved reductions in nominal fleet capacity and fishing effort (Pascoe and Coglan, 2000; Eigaard, 2009).

The effective effort of a fishing fleet is the result of measurable and non-measurable capacity inputs and fishing activity (Figure 1). Fleet capacity is generally expressed in terms of the number, size (GRT, length) and engine power of vessels of specific types (trawlers, seiners, long liners) and the nominal effort can be expressed as the time spent at sea by all vessels of a particular type and engine power using a specific gear and mesh size (Figure 1). Nominal effort is the measurable component of effective effort and can be estimated from routine catch and effort monitoring programmes (FAO, 2000; FAO, 2004). The non-measurable component captures the technical efficiency (catchability) of the vessels as affected by a variety of factors, 
such as differences in the skills of skippers (Hilborn, 1985), differences in the targeting of specific species (Quirijns et al., 2008), or differences in auxiliary equipment (e.g., gear rigging, deck equipment, hull material and propulsion of the vessel) (Marchal et al., 2007).

[Figure 1]

The measurable capacity and activity of the fleet is the basis for fisheries management, which comprises both long-term capacity management and short-term management (Figure 1). Capacity management takes a long-term perspective to match fleet capacity with productivity of the exploited ecological system, and can be undertaken through licensing or by market based approaches, such as ITQs, discouraging over-investment in fleet capacity. Short-term management aims at regulating fishing mortality by adjusting fishing effort or total allowable catch (TAC) on an annual basis. Direct control of fishing effort (short-term input control) is expected to have certain advantages over TAC regulations such as decreased enforcement costs and reduced discards (Murawski and Finn, 1986; Catchpole et al., 2005; Rijnsdorp et al., 2007). However, the success of effort control as fisheries management strategy is highly sensitive to technological development, to input substitution, and to the resulting efficiency changes of commercial fishing vessels (Rossiter and Stead, 2003; Stefansson and Rosenberg, 2005. In a TAC (output) controlled system these effects are in theory selfadjusting (Charles, 1995; Thomsen, 2005), but in many cases technological development also challenges sustainability of this regime type by adding uncertainty to the stock assessments underlying the setting of TACs (Marchal et al., 2002). Hence, it is the changes and variations in the non-measurable inputs that are responsible for many of the problems fisheries management face. The "non-measurable input" term captures factors that are not measured on a routine basis, but require detailed statistical analysis of the available survey and fisheries monitoring data or detailed monitoring of the developments in fisheries technology and changes in fishers skills and behaviour (Salas and Gaertner, 2004, Eigaard et al., 2011a, Andersen et al., 2012).

The objective of this paper is to discuss and review (1) developments in fishing technology that are not routinely monitored; (2) the economic, sociological and regulatory drivers of these developments; (3) the change in catchability in various fisheries and (4) the implications of technological change for the management of fisheries. We deliberately focus on the physical variables that increase the ability of individual vessels to inflict higher fishing mortalities, rather than the input variables used in econometric techniques where production functions are used to relate fleet landings to various measurable inputs, including fixed 
inputs, such as technology, variable inputs, such as fishing days, and to stock size (Hutton et al., 2008). We first describe the introduction of new technology in vessels and fleets, and then analyse its effects on catchability and fishing mortality.

The implications for management focus on (i) how long-term input control (buy-back schemes and other capacity control measures) is challenged by efficiency changes from both temporal (changes at vessel level) and structural (changes in fleet profile) technological development, (ii) how short-term input control (in terms of effort restrictions) can be undermined by technologically induced efficiency increases and, (iii) how technological development can complicate output control by adding uncertainty to standard stock assessment. Following this framework, we explore how the main instruments of current fisheries management could best be applied and supplemented to mitigate the conservation shortcomings resulting from technological development in commercial fisheries.

\section{The nature of technological development in commercial fisheries}

Commercial fishers constantly introduce technology to remain economically competitive and to enhance the performance of their equipment in order to increase the value of their catch, decrease costs, aid navigation, and improve safety at sea (Valdemarsen, 2001; Tietze et al., 2005). Technological development in commercial fisheries is a complex process with many patterns and drivers of introduction and with heterogeneous and occasionally contradictory effects on catchability and fishing mortality. Even though it is broadly accepted that there is technological development (often referred to as technological creep) and that this development complicates sustainable management of commercial fisheries (e.g. Cunningham and Whitmarsh, 1980; Standal, 2005; Eigaard et al., 2011a), relatively little is known about the process. Consequently, incorporating the effects of changes in technological development in fisheries management is far from straightforward.

\section{Technology development and uptake in fisheries}

In the scientific fisheries literature, technological developments are often divided into sudden and gradual incremental change (e.g. Rahikainen and Kuikka, 2002; Marchal et al., 2007). Thus, technological development includes both distinct investments in new technology on board individual vessels (e.g. the purchase of sonar, gear sensors or new navigation systems), as well as gradual improvements to the existing 
vessel technology or gear (e.g. netting materials, trawl panels designs, hook and long line designs or deck equipment and its arrangement). Examples of radical technological change in fisheries is the introduction of purse seining in the late 1960s in the herring (Clupea harengus, Clupeidae) fisheries (Whitmarsh et al., 1995) and the introduction of beam trawls and tickler chains in the Dutch flatfish fishery in the early 1960s (Rijnsdorp et al., 2008). In less than 10 years the Dutch demersal fishery changed from an otter trawl fishery to a beam trawl fishery whereas the increase in engine power more gradually increased over a 40 year period (Figure 2) thus illustrating the concept of two different modes of technological development in fisheries.

[Figure 2]

Sometimes the pace of technological development is related to vessel size, as shown by the introduction of GPS in Danish otter trawlers (Eigaard, 2009), where the proportion of large vessels using GPS increased faster than it did for the smaller vessels (Figure 3).

[Figure 3]

Gear type may also be important. In the Danish fleet, sonars are more common on larger gill netters than on similar sized otter trawlers (Figure 4). Differences in technology investments among vessel types and sizes exist for a range of electronic equipment (Eigaard, 2009), and may reflect heterogeneous gear types, target species and fishing areas, but also costs of buying the equipment relative to the economic turnover of the vessel.

[Figure 4]

The differences between vessel types and sizes are probably less pronounced when it comes to gradual technological improvement of e.g. trawl panel designs or deck equipment. Such changes are often made with little investment, and thus more likely to be accessible to small vessels with moderate turnovers. Regardless of development mode, these differences in the speed of uptake and dissemination of new technology do, however, underpin the fact that integrating temporal and structural technological development in fisheries management cannot be considered a trivial task.

\section{Drivers of technological development}

Before identifying and quantifying the biological effects of technological development in commercial fisheries, it is important to understand the technological developments in an economic and social context. Put 
simply, fishermen have four basic motivations to update technologies: i) to increase revenue by catching more, ii) to increase revenue by raising the value of the catch, iii) to reduce the costs of fishing and, (iv) to enhance comfort and safety on-board. These main incentives for investment are expected to vary somewhat with time according to the regulations in force. For instance it has been demonstrated in the Faroese pair trawl fishery that a regime shift from TAC control to effort regulation induced a 50\% increase in saithe (Pollachius virens, Gadidae) catches per day. This was achieved by replacing older vessels with modern ones of same nominal capacity, which enabled increased towing speed, and ultimately swept area per day (Thomsen, 2005).

\section{[Figure 5]}

Catch increase and reduction of non-fishing time at sea were the most frequent motives for technology investments of Danish trawlers and gill netters in 2005 (Figure 5A) and most investments were related to gears and electronics (Figure 5B) (Marchal, 2006). Both of the primary incentives indicate that the fishers prefer technologies that influence the catch efficiency at the level of the trip.

To better understand how technological development can influence fishing mortality the catch per fishing trip can be viewed as depending on 3 terms that all are subject to optimisation by fishers:

$$
\text { Catch/trip }=\mathrm{q} * \text { Density } * \text { Effort utilisation }
$$

Where $q$ is the catchability of the vessel during the capture process, the "density" term acknowledges that fishers seek particular grounds with high abundance of fish using various types of electronic equipment, and the "effort utilisation" term designates the proportion of the trip that is actually used for the searching and capture processes.

The catchability, q, is typically influenced by technological improvements of the gear deployed, although other factors (e.g. skipper skills) can also be important. The introduction of twin trawling is an example of a gear related change in catchability that happened in many demersal fisheries during the last approx. 25 years (Rihan, 2005; Marchal et al., 2007). Twin trawling affects catch through direct changes in q because it increases the total wing end spread of the gear (Sainsbury, 1996). Similarly the increase in engine power in the Dutch beam trawl fleet (Figure 2) allowed an increase in fishing speed, gear width and the application of tickler chains to chase the flatfish out of the sea bed (Rijnsdorp et al., 2008). Other gear-related technological 
developments with influence on catchability took place in pelagic trawl designs (Rahikainen and Kuikka, 2002) and in the use of thinner and stronger synthetic materials for trawl netting which reduced the drag of the trawl, allowing reduced fuel consumption, faster towing speed and larger trawl size (Eigaard et al., 2011b). Gill net efficiency has also improved substantially through the introduction of synthetic fibres used for thinner, stronger and more transparent filaments (Valdemarsen, 2001).

The “density" term is influenced by electronic developments or devices to aggregate fish. Electronics allow faster and more precise location of productive fishing grounds, facilitates the finding of fish aggregations, and provides improved possibilities for avoiding undersea obstacles such as wrecks or isolated reefs that might otherwise damage towed gear. The most obvious technological developments are echo-sounders and sonars which are used for detection of fish shoals and sea bed type and morphology, and GPS and plotters that are used for positioning. As an example GPS and plotters had resulted in a $12 \%$ increase in vessel fishing power three years after their introduction in the Australian tiger prawn fishery (Robins et al., 1998). However, another study (Mahévas et al., 2011) did not find any significant effect on catchability from the introduction of GPS in four demersal North Sea fisheries, thus illustrating the necessity to interpret each technology in a fishery specific context. Part of the explanation is probably that in the North Sea, the GPS can be considered a replacement of an existing "Decca navigator” system, whereas in most Australian coasts there was no such system before the GPS introduction. Another area where electronics have affected efficiency via the "density" term is the increased precision in manoeuvring and fine-scale navigation. This makes it possible for vessels to fish in previously "non-fishable” areas e.g. stone reefs and areas close to rocks and wrecks, and will allow fishers to stay put and return to high density locations, which may increase the catch rate by as much as $20 \%$ (Rijnsdorp et al., 2011). The relatively rapid uptake of sonars by large Danish gillnetters (Figure 4), who use sonar for positioning their nets close to wrecks, is an example of this (Eigaard, 2009). New designs in trawl ground gears such as bobbins and rock hoppers have also contributed to increase the number accessible fishing grounds. In theory such expansions of the fishable area (or proportion of population exploited) should only result in a temporary increase in catch until the density of the previously unfished area is reduced to the level characteristic for the entire fishable area. However, habitats such as wrecks have been shown to continuously attract fish such as cod (Wilhelmsson et al., 2006; Arena et al., 2007) and it seems therefore reasonable to assume that improved fine scale navigation has created a permanent availability increase. 
Artificial light to attract fish and improve catch efficiency has been used since pre-historic times (Galili and Rosen, 2008). At present it is used for instance in fisheries for pelagic schooling fish and in squid jigging (van Oostenbrugge et al., 2002; Maxwell et al., 2004). Another important method to attract fish is the use of fish aggregation devices (FADs). Since the 1960s, floating objects have been increasingly used to increase the catch efficiency of purse seine fisheries by aggregating tuna species (Dagorn et al., 2012).

The "effort utilisation” term is typically influenced by development of deck equipment such as drums and winches. In many fleets the automation of catch sorting trays and introduction of powered conveyor belt for efficient sorting has resulted in faster on board pre-processing of the catch. In addition, increased durability of gears and improved electronic equipment have reduced non-fishing time at sea and increased vessel efficiency substantially over time (Rijnsdorp et al., 2008; Thomsen, 2005). Verbal information from Danish fishermen indicate a doubling of actual fishing time over non-fishing time in 25 years in the Danish seine fishery, owing mainly to the development of hydraulics and seine rope winches (Figure 6).

[Figure 6]

Although the primary incentives for technological development on board fishing vessels are related to catch increases supposedly fishing mortality neutral motives of increasing comfort and safety are relatively widespread drivers of technological development on board Danish demersal trawlers and gill netters (Figure 5a). Even technological investments which can be expected to result in reduced fishing mortality, such as decreasing variable costs through reductions in crew size, downscaling gear size or lowering towing speed to reduce fuel costs, are not infrequent (Figure 5a).

In short, the processes driving technological development and the resulting influence on fishing mortality are of a very complex nature. Therefore, the integration of technological creep in management regimes requires more insight into the causality of individual technologies in relation to different vessel types, target species and conservation aspects.

Commercial fishers use a variety of fishing techniques, which are adapted to the characteristics of the species they target. Table 1 gives an overview of the main types of fisheries and the main factors affecting catchability. The characteristics of the target species determine to a large extent the technological characteristics affecting catchability. Hence, for the fisheries targeting pelagic schooling fish, the detection of the fish schools with fish finders is more critical than the actual catching process. For demersal species which 
have a less heterogeneous distribution, and which cannot always be detected using fish finders, catchability is mainly determined by the area swept. The response of the fish will also influence catchability. Fish may swim away from the fishing lines allowing them to be herded and concentrated in the mouth of the trawl. The catchability of demersal species that can be herded will be more related to the door spread of the bottom trawl, while the catchability of species that cannot be herded will be more related to the wing spread (Somerton, 2004; Eigaard et al., 2011b). The catchability for flatfish, digging into the sea bed to escape disturbance, will be affected by sea bed contact of the gear, and in particular by the use of tickler chains that dig into the sea bed (Creutzberg et al., 1987). The catchability for fish who escape by swimming upwards in the water column will be more affected by the length and position of the headline, while species with a downward response will be affected by the length and sea bed contact of the ground rope (Main and Sangster, 1982).

[Table 1]

Put simply, Table 1 is intended as a first step to move the most important components from non-measurable inputs into the measurable inputs to the fisheries system (Figure 1) in order to improve the relationship between fishing effort and F. The table entries should be treated as starting points for discussion of the variables and vessel/fishery groupings that should be included in monitoring of fishing effort in order to achieve more valid descriptors of effective capacity, activity and effort.

\section{Temporal patterns of catchability change from technological development}

Technological development may either result in an immediate and marked change in catchability or in smaller stepwise improvements of q, density or effort utilisation, which in combination can cause a noticeable increase in vessel harvesting capacity with time. Often catchability changes are presented as estimates of annual changes in overall fleet efficiency relative to reference points such as stock indices, reference fleets (vessels that have changed little over time)(Banks et al., 2002; Damalas et al., 2014) or production frontiers (vessels that have been the most efficient over time) (Pascoe et al., 2003; Guttormsen and Roll, 2011).

The overall effects of technologically driven catchability change in commercial fisheries are widely recognized (Standal, 2005; Branch et al., 2006a). Also the European Commission (EC) acknowledges that harvesting capacity increases with time (EC, 2008) and that disregarding technological creep will most likely result in excess fishing capacity and an increased mismatch between nominal and effective capacity. An 
annual 3\% increase in effective harvesting capacity in the form of a linear projection has been suggested as realistic by the European Commission (EC, 2008), and such an increase would have more than offset a substantial reduction in nominal EU fleet capacity achieved through large-scale policies of fishing capacity and effort reductions from 1992 to 2008 (Figure 7). Input regulation of EU fisheries has been implemented through the Multi-Annual Guidance Programmes (MAGPs) over the period 1983-2002, being replaced in 2002 by the "entry exit regime”, both aiming at reducing and restricting fishing capacity (Lindebo, 2005).

[Figure 7]

Marchal et al. (2002) used generalized linear modelling (GLM) to investigate the annual change in fishing efficiency for a number of North Sea fisheries defined by gear type used and species targeted. About half of the fleets showed an increasing efficiency trend over the study period (1987-1998) but only few of these trends were linear (Figure 8). The most frequent pattern seems to be shorter relatively stable periods with moderate trends interrupted by one or two large year-to-year changes, but in general the patterns of efficiency change with time are very heterogeneous. The overall efficiency changes estimated by Marchal et al. (2002) combines the effect of technological development and changes in fishermen behaviour, but their data does not allow disentangling the contribution of technological development from other factors. Consequently, such integrated estimates are difficult to use for assessing patterns of catchability change resulting explicitly from technological development.

[Figure 8]

O’Neill and Leigh (2007) took another approach by identifying efficiency changes from both temporal and structural technological developments using linear mixed models. They related comprehensive technological vessel data from interviews to logbook catches on a fine spatio-temporal scale allowing estimation of fishing power changes from technological development in six fleets over the period 1988 to 2004. The authors separated fishing power trends into temporal technological changes (fixed terms) and structural technological changes (random terms) due to differences between vessels. The fixed terms are in principle estimates of efficiency change from temporal technological development and consequently usable for assessing validity of a linear projection. The trajectories generally display gradual increases in fishing power with only few largescale annual effects (dotted lines, Fig. 9).

[Figure 9] 
The rate of technology dissemination within fleets may vary across commercial fisheries. In French bottom trawlers of South Brittany the uptake of the GPS technology was very rapid and a fleet dissemination level of 80\% was reached within 3 years from 1988-1990 (Mahévas et al., 2004). On the other hand the spread of this particular technology was much slower and more gradual in several other French and Danish fleets (Marchal et al., 2007; Eigaard, 2009). Considering also the more gradual dissemination patterns for a number of other technologies described in these two papers (e.g. twin trawls, sonars, and trawl sensors), very steep introduction of novel technologies appears to be the exception rather than the rule. This is confirmed by the dissemination patterns of five new technologies within an approx. $10 \%$ subsample of the Danish demersal trawler and gillnet-fleet in 2005, where an index of the combined technology introduction seems to be introduced fairly gradually over the study period for all vessel groups (Figure 10D). The index is calculated as the sum of the yearly uptake percentages of individual technologies by vessel groups (Figure 10A,B,C).

[Figure 10]

Although the combined introduction of twin trawl, split winch, kort nozzle, gear sensors and GPS was quite rapid in the early eighties for both trawler groups (Figure 10D), thereby distorting somewhat the impression of a smooth temporal technology development across the period, the technology uptake itself is only indicative of the resulting efficiency change. Often vessels require a time lag to fully benefit from e.g. GPS and plotter introduction (Robins et al., 1998), which would smoothen out the catchability impact, and based on the trajectories of combined technology introduction in the Danish demersal fleet (Figure 10D) and the technological efficiency change in the different Australian prawn and scallop fleets (Figure 9) a linear long term projection of fleet efficiency increases from technological development seems reasonable.

\section{Quantification of catchability change from technological development}

Estimates of change in catchability resulting from technological development are presented in Table 2, which is based on the available literature. As discussed previously, most of the papers on catchability changes in fisheries provide annual changes based on analyses of landings and effort data kept in national databases. These data reflect three types of signals: (i) the variation in stock abundance, (ii) changes in fishermen behaviour, and (iii) technological development. The signal from variations in resource abundance can in theory be separated from the two others by using independent stock data from assessments and surveys (e.g. 
Marchal et al., 2002; Banks et al., 2002). However, unless sufficient external technology or behaviour data are brought into the analyses of landings and effort data, as done by Rijnsdorp et al. (2006) and O’Neill and Leigh (2007), only the combined effect of fishers' behaviour and technological development can be estimated.

The problem of separating the factors resulting in overall efficiency change of commercial fleets is also reflected in the summary of the quantitative efficiency estimates in Table 2. The estimates represent a variety of methods, models, variables, periods of investigation, case studies and outcomes, and are as such not directly comparable. To avoid this problem the outcomes are grouped in two categories of efficiency estimates: i) those directly attributable to technology specified in the analysis/model, and ii) those attributable to all that is not explicitly analysed/modelled - typically fishermen behaviour/skipper skills, regulatory constraints and varying subsets of vessel technology (frequently in the form of a year effect in the models). Although far from being exact, this grouping allows us to estimate the annual percentage efficiency change (arithmetic mean) by vessel types, which can be used for assessing the order of magnitude of annual catchability increases from technological development. Having said this, it is worth underpinning that the average values should be treated with caution; a weakness of practically all the investigations is the applicability and reliability of the stock abundance data. In several studies, this aspect of uncertainty is described by the authors as a reason for treating their results only as indicative (e.g. Kirkley et al., 2004). Even so, the Table 2 values are currently the only data readily available for assessing the magnitude of catchability increases with time in fisheries, and for providing a quantitative basis for assessing management implications of technological creep.

[Table 2]

Keeping in mind that the studies reflected in Table 2 cover different periods, fishing areas, fleets and target species, the main results that can be derived are that temporal technological development has enabled an annual efficiency increase of about $1.0 \%$ in demersal trawl fisheries, of $2.0 \%$ in beam trawl fisheries and of 6.7\% in long line fisheries (no empirically based estimates of technological creep were available for gill net fisheries or seine fisheries), leading to an average of 3.2\% across vessel types.

In conclusion, the assumption of a linear projection of catchability increase appears at first sight to be at odds with the sudden and rapid technology introduction observed in certain vessel groups (e.g. Figure 3). However, at the fleet level the overall dissemination pattern is more even due to the different uptakes for 
different vessel sizes, ages and types. Many technologies have a (variable) lag time of up to several years before being fully utilized on board the vessels (Robins et al., 1998), thus delaying the catchability effects following even very rapid uptakes. Obviously the vessel types differ with respect to annual catchability change, e.g. long liners $6.7 \%$ and beam trawlers $2 \%$, and different annual percentages should probably be used for the main vessel groups defined in Table 1 . Due to the variability within and between vessel types the assumed 3\% annual increase in overall EU fleet catchability proposed by the EU Commission seems to be fairly in line with the overall average of 3.2\% based on the literature review (Table 2).

\section{Management implications of technological development}

A yearly catchability increase of about 3.2\% could arguably be one of the main reasons that many of the world's fisheries are suffering from declining resources (FAO, 2012). To solve the problems of balancing harvesting capacity and resource size management institutions have applied a variety of tools, often with mixed success (Hilborn et al., 2004). Three main types of management approaches can be identified: (i) inputbased capacity management (long-term), (ii) input-based effort management (short-term) and (iii) outputbased (TAC management (short-term)), which are all somehow challenged by technological creep.

\section{Input-based capacity management}

Input-based capacity management should in theory be suited for eliminating over-capacity. However, the examples of long-term capacity control so far (e.g. the buy-back schemes and the MAGPs of the CFP) have suffered from the same inability to deal with catchability increases as short-term input control, and have furthermore been vulnerable to efficiency increases from changes in fleet composition (Lindebo, 2005). Although structural technological development can take place without being instigated by management initiatives, the rate at which development takes place is increased by buy-back schemes, where older, smaller vessels often become replaced with newer, larger vessels within a fixed or reduced nominal capacity limit (e.g. total fleet tonnage or total fleet kilowatt). In addition, nominal capacity reduction in fleet level may thus be undermined by the increased fishing power of the newer and larger vessels in the restructured fleet (Hilborn, 1985; Pascoe and Coglan 2000; Pascoe et al., 2001a). Consequently, some projection of efficiency increases with time is needed to account for the effects of technological creep on long-term capacity control as 
also pointed out by the European Union Commission (EC, 2008). Technological development can result in effective capacity becoming more and more decoupled from nominal capacity, and this is particularly so when long term capacity targets are accompanied by fleet modernisation programmes. Eigaard (2009) demonstrated that the level of technological equipment on board Danish trawlers and gillnetters increases with vessel length and with decreasing vessel age as well as with time. He also separated the two main technological mechanisms driving the decoupling between effective and nominal capacity: 1) structural technological development in fleet level (small, old vessels being replaced with newer, larger and better equipped ones) and, 2) improvement of individual vessel and gear technology over time. Both mechanisms are documented to increase fleet efficiency in other studies (Pascoe et al., 2001a; Rijnsdorp et al., 2006), and need to be explicitly addressed when launching modernization programs and setting long term capacity targets.

\section{Input-based effort management}

The main advantages of short-term input-based effort management (e.g. a yearly effort restriction of days at sea) are argued to be easy enforcement and monitoring, improved regulation legitimacy and compliance among fishermen, and limited incentives to discard, high-grade or misreport (Murawski and Finn, 1986; Rossiter and Stead, 2003; Shepherd, 2003). Consequently, the catch and effort data feeding into scientific stock assessments would be more reliable, dumping and waste of caught fish would be reduced, and intended fishing mortality would in principle better match realized fishing mortality (Daan, 1997; Rijnsdorp et al., 2007). However, the main shortcoming of short-term input control of effort is that it relies heavily on the ability to predict catchability changes, an ability vulnerable to technological development and efficiency changes (Stefansson and Rosenberg, 2005; Jákupsstovu et al., 2007). Temporal technological development has in the past offset reductions in allocated fishing days or capacity (Rossiter and Stead 2003; Catchpole et al., 2005), and projecting efficiency increases and predicting the patterns of catchability change are by no means trivial tasks. The inherent uncertainty of mixed fisheries makes it even more difficult to match intended and realized fishing mortality accurately (Rijnsdorp et al., 2006; Ulrich et al., 2012), and this compromises the achievement of management objectives. Another problematic aspect of input control in mixed fisheries without catch limitations, is the ability of fishermen to target any fish species, including high-value species with low stock levels (Rossiter and Stead 2003; Eigaard et al., 2011a). Consequently, short-term input control, 
particularly in mixed fisheries, require substantial additional regulation, including output control, as well as the identification and quantification of appropriate nominal effort descriptors and efficiency projections.

\section{Output-based TAC management}

Output control may provide better agreement between intended and realized fishing mortality than input control. This requires, however, that the biomass estimates and projections from which TACs are calculated are correct, and that TACs are efficiently enforced. As a result, the main weaknesses of output control are imprecise estimates of stock size owing to e.g. mis-specification of biological parameters, poor coverage of surveys, and to over-quota catches due to discarding or misreporting (Raakjær and Mathiesen 2003; Catchpole et al., 2005; Branch et al., 2006). If commercial catch per unit effort (CPUE) data are used in the assessments, the setting of appropriate TACs can also be seriously biased by catchability changes owing to i) technological development (Marchal et al., 2003; Eigaard and Munch-Petersen, 2011), ii) fishermen behaviour such as improved skipper skills, targeting behaviour and technical interactions (Marchal et al., 2006; Poos and Rijnsdorp, 2007; Fulton et al., 2011), and iii) biological factors such as changes in spatial distribution and availability of target species due to environmental conditions (Horwood and Millner, 1998; Rose and Kulka, 1999). As such, the undesired effects of technological development are limited in output-controlled fisheries and mainly restricted to inaccuracy within any stock assessment model using commercial CPUE time series to tune. When this is the case, assessment procedures should be scrutinized for bias from fishing power trends on a regular basis and the time series should be standardized accordingly (Braccini et al., 2012).

\section{Discussion}

\section{Capacity descriptors and projections}

The current measures of nominal capacity deployed in commercial fisheries worldwide do not sufficiently well reflect the actual harvesting capacity (effective capacity) of the fleets (FAO, 2004; EC, 2008). Clearly, better descriptors are needed to capture efficiency increases from structural change. Pascoe et al. (2001b) included vessel size and engine power in a nominal capacity expression, and evaluated its reliability by comparing it to a comprehensive fishing-capacity expression generated by data envelopment analysis. The 
evaluation demonstrated that the expression reasonably well approximated the effective capacity of mobile gears, but not of static gears. Another capacity expression (a capacity factor), used by Standal (2007) to assess the success of the Norwegian unit quota system, included a gear factor (single or double trawl) along with an engine-power factor and three vessel-size factors and revealed a substantial mismatch between nominal and effective capacity in the Norwegian trawl fishery. Using integrated capacity expressions when planning, implementing, and evaluating structural measures would take into account some of the unintended increases in harvesting capacity that often accompanies directed capacity plans. According to the model results in Eigaard (2009), the inclusion of vessel size and vessel age in an integrated nominal capacity expression would most likely account for fishing power increases resulting from technological development of fish-finding and navigation-equipment. The importance of gear factors (e.g. single/twin trawl and ground gear type) in describing catchability is confirmed by the findings of Marchal et al. (2007) and of Reid et al. (2011).

Based on the above referred experiences vessel length, vessel hp and vessel age in combination with some gear factors, could in principle help refining the definition of capacity metrics for a number of fisheries. However, the practical application of such an approach is compromised by three important shortcomings. First, appropriate gear factors may vary from one species to another as summarized in Table 1 and also demonstrated in a number of studies (e.g. O’Neill et al., 2003; Marchal et al., 2007; Eigaard et al., 2011a,b).

Second, horsepower, tonnage and vessel length are not very good descriptors of effective capacity in fisheries with static gears (Pascoe et al., 2001b; Marchal et al., 2002). Therefore, a single capacity expression covering all commercial vessel groups participating in the fishery is difficult to imagine and a tradeoff is inevitable between the level of accuracy and the need for an operational metric that can be easily monitored and regulated. Different tradeoffs and suggestions for operational integrated capacity expressions for main vessel groups are explored further, based on the descriptors in Table 1, and summarized below in the section on technological challenges to effort management.

Third, even if improved integrated fleet capacity descriptors and projections could successfully be identified and implemented, they would only mitigate the effect of structural technological developments (changes in fleet profiles). The temporal (within vessel) technological development, and thus the future efficiency changes from e.g. increased gear catchability or improved fish finding and navigation equipment, cannot be sufficiently captured no matter what the complexity and accuracy of the capacity expressions of the present. 


\section{Effort descriptors and projections}

The fishing effort term can be considered a combination of fishing capacity and activity. This is consistent with figure 1 , and reflects that most of the mismatch between nominal and effective capacity discussed above has direct relevance for effort management. This also implies that including more refined capacity descriptors and projections of efficiency increase could somehow alleviate the undesirable effects of technological creep and might improve the performance of direct effort management. Similar to fishing capacity, any mismatch between nominal and effective fishing activity would adversely alter the performance of effort management. In the terminology established in the opening sections, effective fishing activity translates to effort utilization at sea, which is strongly influenced by technological development and can have substantial effect on catch efficiency of seiners, trawlers and beam trawlers (Figure 6; Thomsen 2005; Rijnsdorp et al. 2008).

The suggestions for improved effective effort descriptors and additional logbook variables (Table 1) were established with the objective of more accurately reflecting the main motivation of fisheries to increase catches through optimizing q, density and effort utilization based on current technology. However, no effort descriptor can capture the influence of temporal technological development on the catchability of the gears deployed in the future. Therefore, it seems realistic to project increases in gear catchability over future time periods - at least for the five non-pelagic vessel types, where the catch process is more important than the search process. According to the results in Table 2, the magnitude of such a projection of gear catchability increases would need to be identified by each vessel/gear type and implies a research need for developing methods for efficiency projections for input based management. The suggestions for accurate effort descriptors (second last column, Table 1) have been made under the assumption of full compliance from fishermen and absence of technical data handling problems. This is a simplification and if, for instance, the activity descriptors on a fine scale (e.g. number of seine hauls per trip per area) are considered to be difficult to quantify, another option could be to incorporate expected increases from improved effort utilization with time in catchability projections. Such an approach would enable using a more operational activity descriptor, e.g. days at sea, but it would also reduce the ability of nominal effort descriptors to accurately reflect effective effort - and it would require an intensive effort to quantify valid integrated projections by vessel group. 
In this discussion the increasing amount of VMS (Vessel Monitoring System) data being generated and explored (Hintzen et al., 2012; Bastardie et al., 2013) should also be brought forward and these data point in the direction of effort descriptors on a finer spatial and temporal scale. With the vessel groupings and effective capacity and activity summary of Table 1 the basis for identifying valid effort descriptors for aggregate vessel groups is certainly improved. The suggestions for effort descriptors, however, represent a tradeoff between the accuracy in reflecting adverse biological effects of very heterogeneous fisheries and the need for the effort descriptors to be operational in terms of applicability and routine monitoring. Therefore, it remains to be seen whether such aggregate descriptors are sufficiently robust to the species specific effects of many technologies (O’Neill et al., 2003; Eigaard et al., 2011a,b) and of the skippers’ effect (Branch and Hilborn, 2008; Quirijns et al., 2008). The more complex and detailed the effort descriptors, the more difficult it is for managers to monitor and enforce them. This is a key issue and a potential problem of any effort regulation system (Martell and Walters, 2002; Shepherd, 2003; Rijnsdorp et al., 2007). Thus, the consequences of inaccurate effort descriptors and quotas have recently been demonstrated to result in an overfishing of Faroese cod and haddock (Melanogrammus aeglefinus, Gadidae) stocks (Jákupsstovu et al., 2007).

\section{Accounting for technological creep in stock assessment}

When time series of commercial CPUE data are employed for stock assessment, either directly as an indicator of fishable biomass or indirectly for tuning age-based stock assessment models, technological development can potentially bias assessment results and thus the scientific basis for setting TACs in output controlled management regimes (Maunder et al., 2006). If cpue corrections for technological creep are assessed to be necessary different approaches can be taken, depending among other on data availability and the number of additional factors other than abundance that need to be adjusted for (Maunder and Punt, 2004). Changes in fleet profiles, management regulations, skipper skills, and in the availability of the species are additional factors that can influence trends in catch rates (Bishop 2008).

In situations where only bias from technological creep needs to be removed from commercially based abundance indices, a simple bottom-up approach can be taken, where the essential step is to obtain detailed information of technology change of the time series. In some cases technological information can be obtained from logbooks or other official statistics, but most often this step will require industry consultation (Eigaard et 
al., 2011a; Braccini et al. 2013). Eigaard and Munch-Petersen (2011) used net maker interviews to identify substantial gear size increases of a CPUE time series used for northern shrimp (Pandalus Borealis) stock assessment in the North Sea. A significant engine power $\sim$ trawl size relationship was established from the interview data and subsequently used in a GLM-standardization of the commercial effort data, which resulted in a substantially altered perception of stock size and trends. Comparable results on the importance of scrutinizing commercial catch and effort have been demonstrated for a number of prawn and scallop fisheries in Australia (O’Neill et al. 2003; O’Neill and Leigh 2007).

A similar approach can be used even if technological creep is only one of more factors to correct for, but the traditional CPUE standardisation tools such as generalized linear models, mixed models, and generalized additive models (Maunder and Punt, 2004), can only correct for informed factors. As for technology change, data for other factors is not always readily available. Therefore relevant information (of e.g. shifts in management regimes or environmental conditions) from additional (non-logbook) sources is often required before corrections can be made.

An alternative approach is to use methods that allow catchability to vary over time within an assessment model such as random walks, state space models or other techniques that model catchability as a function of time (Wilberg et al., 2010; Thorson, 2011). These techniques do not ascribe causation or separate the factors responsible for changes in catchability, which is of course an advantage in relation to data requirements, but a weakness in relation to transparency and interpretation of results. In this review, where technological development itself is the subject of investigation, these methods are not dealt with in detail, but only presented briefly as potential ways of correcting for technological creep in stock assessments.

In assessments where technological creep is assessed to be substantial and not feasible to correct for using one of the above approaches - and fishery-independent data do exist (e.g. research survey data or mark recapture data) - another option is to rely entirely on the scientific data (Thorson, 2011).

\section{Conclusion}

Whatever the management system in force, technological development and catchability increases will occur. But even though the development of technology is inevitable and almost indifferent to the regulation type (Whitmarsh 1990; Eigaard et al., 2011a) the sensitivity of the different management strategies to the undesired 
effects of technological development is far from identical. Focusing on the challenges caused by technological creep in relation to over-capacity, discarding, misreporting, and stock assessment, our review suggests that management challenges from technological development seem more difficult to resolve for input-oriented fisheries policies than for output-based ones. Considering the heterogeneity of biological effects, the task of achieving agreement between intended (effort restrictions) and realized fishing mortality appears particularly difficult. The heterogeneity of the technological challenges is not only restricted to the development of different technologies in different fisheries, or different use of the same technologies in different fisheries (e.g. the use of sonar technology for fish finding in pelagics as well as for small scale navigation in wreck fishing with gillnets), but also to species-specific effects of the same technology development in the same fishery. For instance, the combined development of skewed hooks and swivel line in the Faroese long line fishery resulted in a 51\% increase in haddock catchability but only half that (26\%) in cod catchability (Eigaard et al., 2011a).

Bearing this complexity in mind, and adding to it the need to also identify and predict catchability changes from factors such as targeting behavior, skipper skills, technical interactions, compliance, contraction of the stocks and environmental conditions, the pendulum of this review swings towards favouring output control and coping somehow with discards and misreporting - rather than attempting to manage fishing mortality levels through expected matching levels of fishing effort. In this consideration the need for proper enforcement is acknowledged (Branch et al., 2008) and also recent successful experiments with fully documented fisheries potentially enabling transition from landing quotas to actual catch quotas have played a part (Kindt-Larsen et al., 2011). Quota transferability, in combination with discard bans and over quota landing taxes may also improve catch-quota balancing in mixed fisheries, and thereby provide appropriate incentives to discourage over quota discards (Branch et al., 2006b; Marchal et al., 2009; Poos et al., 2010).

If, however, the benefits of reduced discards, misreporting and enforcement costs of short-term input control are assessed more important than the relative insensitiveness of TAC management to the effects of technological creep (and the other factors influencing catchability), it is crucial to equip such a system with tools to counteract catchability increases from technological development. Consequently, accurate and operational nominal descriptors of effective capacity and effort are prerequisites of long- and short-term input control systems and need to be supplemented with realistic long- and short-term projections of efficiency increases from technological development. 
In addition to the management challenges discussed above, aspects of technological development have also brought about a number of positive contributions to commercial fisheries. Thus, according to Gislason (2006), gear developments are key requirements of moving towards an Ecosystem Approach to Fisheries Management (EAFM). Various gears are increasingly being modified to improve selectivity, minimize their side effects on benthic habitats and fauna, and reduce unwanted by-catch. Sorting grids, turtle exclusion devices (TEDs) and escape windows have proven capable of reducing by-catches and discards of trawlers, and are already mandatory in a number of fisheries for fish and crustaceans (Valdemarsen and Suuronen, 2003; Madsen et al., 2010: Eigaard et al., 2012). Acoustic pingers, high density filaments and coloured netting can help reducing the entanglement of marine mammals and sea birds in gill nets (Larsen et al., 2007; Bull, 2007; Carlström et al., 2009) and a series of changes in gear design and operating practices has substantially reduced dolphin bycatches in tuna seine fisheries (Hall, 1998). Also the general improvement of technology and vessel fishing power could potentially be an environmental asset. This could be the case in fisheries managed by TAC in combination with a well-monitored ban on discard practices (Batsleer et al., 2013). Increased efficiency would then reduce operating costs as the same allowed quantity of fish would be caught with less effort (e.g. in fewer fishing days, less area swept or using less fuel), resulting in less environmental impact (Thomsen, 2005). In relation to meeting long term sustainability goals, the utility of the technological development in commercial fisheries is, however, strongly dependent on the regulations in force, and management should take care to provide the right incentive base (Graham et al., 2007). These latter conservation potentials of technological development are numerous and deserve a thorough presentation, but are only treated in a more rudimentary manner in this review, where focus is on the task of accounting for the above-described side effects of technological development in modern fisheries management in order to better meet sustainability objectives.

\section{Acknowledgements}

This work was partly funded by the EU-DG Fisheries through the FP7 projects MYFISH (Maximising yield of fisheries while balancing ecosystem, economic and social concerns) and SOCIOEC (Socio economic effects of management measures of the future CFP) and partly by the EU-Interreg IVA-152207 project: "Bärekraftig rekefiske i Skagerrak”. This support is greatly acknowledged. Also many thanks to Holger Hovgaard for having pointed out the need to specifically address the role of technological development in 
fisheries management and for having inspired us to write this paper. The thorough and constructive criticism from the anonymous reviewers is also greatly appreciated.

\section{References}

Andersen, B.S., Ulrich, C., Eigaard, O.R., Christensen, A.S. Short-term choice behaviour in a mixed fishery: investigating métier selection in the Danish gillnet fishery. ICES J. Mar. Sci. 69: 131-143 (2012).

Arena, P., L. Jordan, R. Spieler, G. Relini, J. Ryland, and H.J. Dumont. Fish assemblages on sunken vessels and natural reefs in southeast Florida, USA. In: Biodiversity in Enclosed Seas and Artificial Marine Habitats, Vol. 193. Developments in Hydrobiology (Ed. H.J. Dumont), Netherlands, pp. 157-171 (2007).

Banks, R., S. Cunningham, W.P. Davidse, E. Lindebo, A. Reed, E. Sourisseau, and J.W. de Wilde. The impact of technological progress on fishing effort. LEI Report, PR.02.01 (2002). http://applicaties.wageningenur.nl/wever.internet/applications/leirapporten/defaultuk.aspx?id=284 [accessed 29 November 2013]

Bastardie, F., J.R. Nielsen, B.S. Andersen, and O.R. Eigaard. Integrating individual trip planning in energy efficiency - Building decision tree models for Danish fisheries. Fish. Res., 143: 119-130 (2013).

Batsleer J., J.J. Poos, P. Marchal, Y. Vermard, and A.D. Rijnsdorp. Mixed fisheries management: protecting the weakest link. Mar. Ecol. Prog. Ser., 479: 177-190 (2013).

Bishop, J., W.N. Venables, C.M. Dichmont, and D.J. Sterling. Standardizing cathc rates: is logbook information by itself enough? ICES J. Mar. Sci., 65: 255-266 (2008).

Braccini, J.M., M.F. O’Neill, A.B. Campell, G.M. Leigh, and A.J. Courtney. Fishing power and standardized catch rates: implications of missing vessel-characteristic data from the Australian eastern king prawn (Melicertus plebejus) fishery. Can. J. Fish. Aquat. Sci., 69: 797-809 (2012).

Branch, T. A., R. Hilborn, A.C. Haynie, et al. Fleet dynamics and fishermen behaviour: lessons for fisheries managers. Can. J. Fish. Aquat. Sci., 63: 1647-1668 (2006).

Branch, T.A., K. Rutherford, and R. Hilborn. Replacing trip limits with individual transferable quotas: implications for discarding. Mar. Policy, 30: 281-292 (2006b).

Branch, T.A. and R. Hilborn. Matching catches to quotas in a multispecies trawl fishery: targeting and avoidance behaviour under individual transferable quotas. Can. J. Fish. Aquat. Sci., 65: 1435-1446 (2008). 
Catchpole, T.L., C.L.J. Frid, and T.S. Gray. Discards in North Sea fisheries: causes, consequences and solutions. Mar. Policy, 29: 421-430 (2005).

Charles, A.T. Fishery science: the study of fishery systems. Aquat. Living Resour., 8: 233-239 (1995).

Creutzberg, F., G.C.A. Duineveld, and G.J. Van Noort. The effect of different number of tickler chains on beam trawl catches. ICES J. Mar. Sci., 43: 159-168 (1987).

Cunningham, S., and D. Whitmarsh. Fishing effort and fisheries policy. Mar. Policy, 4: 309-316 (1980).

Daan, N. TAC management in North Sea flatfish fisheries. Journal of Sea Research 37: 321-341 (1997).

Damalas, D., C. D. Maravelias, and S. Kavadas. Advances in Fishing Power: A Study Spanning 50 Years. Rev. Fish. Sci. 22: 112-121 (2014).

Dagorn, L., K.N. Holland, V. Restrepo, and G. Moreno. Is it good or bad to fish with FADs? What are the real impacts of the use of drifting FADs on pelagic marine ecosystems? Fish and Fisheries, DOI: 10.1111/j.1467-2979.2012.00478.x (in press).

EC. Reflections on further reform of the Common Fisheries Policy. EC working document (2008). http://www.cfp-reformwatch.eu/pdf/reflection_cfp_08_mid.pdf [accessed 29 November 2013]

Eigaard, O.R. A bottom-up approach to technological development and its management implications in a commercial fishery. ICES J. Mar. Sci., 66: 916-927 (2009).

Eigaard, O.R., B. Thomsen, H. Hovgaard, A. Nielsen, and A.D. Rijnsdorp. Fishing power increases from technological development in the Faroe Islands longline fishery. Can. J. Fish. Aquat. Sci., 68: 1970-1982 (2011a).

Eigaard, O.R., D. Rihan, N. Graham, A. Sala, and K. Zachariassen. Improving fishing capacity descriptors: modelling engine power and gear-size relations of five European trawl fleets. Fish. Res., 110: 39-46 (2011b).

Eigaard, O.R., and S. Munch-Petersen. Influence of fleet renewal and trawl development on landings per unit effort of the Danish northern shrimp (Pandalus borealis) fishery. ICES J. Mar. Sci., 68: 26-31 (2011).

Eigaard, O.R., B. Herrmann, and J.R. Nielsen. Influence of grid orientation and time of day on grid sorting in small-meshed trawl fishery for Norway pout (Trisopterus esmarkii). Aquat. Living Resour., 25: 15-26 (2012) 
FAO. Report of the Technical consultation on the measurement of fishing capacity. FAO Fisheries report No. 615, 51 pp (2000).

FAO. Measuring and appraising capacity in fisheries: framework, analytical tools and data aggregation. FAO Fisheries Circular No. 994, 39 pp (2004)

FAO. The State of World Fisheries and Aquaculture (SOFIA). FAO Fisheries and Aquaculture Department, Rome (2012). http://www.fao.org/docrep/016/i2727e/i2727e00.htm [accessed 29 November 2013]

Fulton, E., A.D.M. Smith, D.C Smitf, and I. van Putten. Human behaviour: the key source of uncertainty in fisheries management. Fish Fish., 12: 2-17 (2011).

Gislason, H. The requirements of an Ecosystem Approach to Fisheries Management. In: The knowledge base for Fisheries management (Eds. L. Motos and D.C. Wilson). Developments in Aquaculture and Fisheries Science 36: 307-328 (2006).

Galili, E., and B. Rosen. Fishing gear from a 7th-century shipwreck off Dor, Israel. Int. J. Naut. Archaeol., 37: 67-76 (2008).

Graham, N., R.S.T. Ferro, W.A. Karp, and P. MacMullen. Fishing practice, gear design, and the ecosystem approach - three case studies demonstrating the effect of management strategy on gear selectivity and discards. ICES J. Mar. Sci., 64: 744-750 (2007).

Guttormsen, A.G., and K.H. Roll. Technical Efficiency in a Heterogeneous Fishery: The Case of Norwegian Groundfish Fisheries. Mar. Resour. Econ., 26: 293-307 (2011).

Hall, M.A. An ecological view on the tuna-dolphin problem. Impacts and trade-offs. Rev. Fish Biol. Fisher. 8: 1-34 (1998).

Hilborn, R. Fleet dynamics and individual variation: why some people catch more fish than others. Can. J. Fish. Aquat. Sci., 42: 2-13 (1985).

Hilborn, R., J.M. (Lobo) Oresanz, A.M. Parma, A.M. Institutions, incentives and the future of fisheries. Philos. T. R. Soc. Lon. B, 360: 47-57 (2004).

Hintzen, N.T., F. Bastardie,D.J.B. Beare,G. Piet,C. Ulrich,N. Deporte, J.Egekvist, andH. Degel. VMStools: open-source software for the processing, analysis and visualization of fisheries logbook and VMS data. Fish. Res., 115: 31-43 (2012). 
Horwood, J.W., and R.S. Millner. Cold induced abnormal catches of sole. J. Mar. Biol.l Assoc. UK, 78: 81-84 (1998).

Hutton, T., S. Pascoe, B. Rackham, and C. O’Brien. A comparison of technical efficiency estimates for seven English fleets in the North Sea from stochastic production frontier (SPF) and Data Envelopment Analysis (DEA). In: Single output measures of technical efficiency in EU fisheries. (Eds. S. Pascoe, and S. Mardle), CEMARE, University of Portsmouth, UK. CEMARE Report 61, pp. 56-70 (2003).

Hutton, T., S. Mardle, and A.N. Tidd. The decline of the English and Welsh fishing fleet? In: Advances in fisheries science: 50 years on from Beverton and Holt. (Eds. A. Payne, J. Cotter, and T. Potter) Blackwell Publishing, Oxford; 2008, pp. 26-48 (2008).

Jákupsstovu, S. H. I., L.R. Cruz,J-J. Maguire,J. Reinert. Effort regulation of the demersal fisheries at the Faroe Islands: a 10-year appraisal. ICES J. Mar. Sci., 64: 730-737 (2007).

Kirkley, J., P.C.J. Morrison, S. Cunningham, and J. Cantzano. Embodied and disembodied technical change in fisheries: an analysis of the Sète trawl fishery, 1985-1999. Environ. Resour. Econ., 29: 191-217 (2004).

Kindt-Larsen, L., E. Kirkegaard, and J. Dalskov. Fully documented fishery: a tool to support a catch quota management system. ICES J. Mar. Sci. 68: 1606-1610 (2011).

Larsen, F., O.R. Eigaard, and J. Tougaard. Reduction of Harbour Porpoise by catch by high density gill nets. Fish. Res. 85: 270-278 (2007).

Lindebo, E. (2005) Role of Subsidies in EU Fleet Capacity Management. Marine Resource Economics 20, 445-466.

Madsen, N., R. Frandsen, R. Holst., and L.A. Krag. Development of new concepts for escape windows to minimise cod catches in Norway lobster fisheries. Fish. Res., 103: 25-29 (2010)

Mahévas, S., Y. Sandon, and A. Biseau. Quantification of annual variations in fishing power due to vessel characteristics: an application to bottom-trawlers of South Brittany targeting anglerfish (Lophius budgegassa, Lophius piscatorius). ICES J. Mar. Sci., 61: 71-83 (2004).

Mahévas, S., Y. Vermard, N. Goascoz, et al. An investigation of human versus technological variation in catchability for a selection of European fleets. ICES J. Mar. Sci., 68: 2252-2263 (2011).

Main, J., and G.I. Sangster. A Study of a Multi-Level Bottom Trawl for Species Separation Using Direct Observation Techniques. Scottish Fisheries Research Report, No 26, 17 pp. (1982). 
Marchal, P., C. Ulrich, K. Korsbrekke, M. Pastoors, and B Rackham. A comparison of three indices of fishing power on some demersal fisheries of the North Sea. ICES J. Mar. Sci., 59 604-623.

Marchal P., C. Ulrich, K. Korsbrekke, M. Pastoors, B Rackham, and H. Hovgård. Variations in catchability and fish stock assessments. Sci. Mar. 67 (Suppl. 1): 63-73 (2003).

Marchal, P. (Editor) Technological developments and tactical adaptations of important EU fleets (TECTAC No. QLK5-2001-01291). Final project report (2006).

Marchal, P., B.S. Andersen, D. Bromley, et al. Improving the definition of fishing effort for important European fleets by accounting for the skipper effect. Can. J. Fish. Aquat. Sci., 63: 510-533 (2006).

Marchal, P., B. Andersen, B. Caillart O.R. Eigaard, O. Guyader, H. Hovgaard, A. Iriondo, F.L. Fur, J. Sacchi, and M. Santurtún. Impact of technological creep on fishing effort and fishing mortality, for a selection of European fleets. ICES J. Mar. Sci. 64: 192-209 (2007).

Marchal, P., P. Lallemand, K. Stokes, and O. Thébaud. A comparative review of the fisheries resource management systems in New Zealand and in the European Union. Aquat. Living Resour., 22: 463-481 (2009).

Martell, S. J. D., and C.J. Walters. Implementing harvest rate objectives by directly monitoring exploitation rates and estimating changes in catchability. B. Mar. Sci., 70: 695-713 (2002).

Maunder, M. N., J.R. Sibert, A. Fonteneau, J. Hampton, P. Kleiber, and S.J. Harley. Interpreting catch per unit effort data to assess the status of individual stocks and communities. ICES J. Mar. Sci., 63: 1373-1385 (2006).

Maunder, M.N., and A.E. Punt. Standardizing catch and effort data: a review of recent approaches. Fish. Res., 70: 141-159 (2004).

Maxwell, M.R., A. Henry, C.D. Elvidge, et al. Fishery dynamics of the California market squid (Loligo opalescens) as measured by satellite remote sensing. Fish. B., 102: 661-670 (2004).

Murawski, S.A. and J.T. Finn. Optimal Effort Allocation among Competing Mixed-Species Fisheries, Subject to Fishing Mortality Constraints. Can. J. Fish. Aquat. Sci., 43: 90-100 (1986).

O’Neill, M.F., A.J. Courtney, C.T. Turnbull, N.M. et al. Comparison of relative fishing power between different sectors of the Queensland trawl fishery, Australia. Fish. Res., 65: 309-321 (2003).O’Neill, M. F., 
and G.M. Leigh. Fishing power increases continue in Queensland's east coast trawl fishery, Australia. Fish. Res., 85: 84-92 (2007).

van Oostenbrugge, J.A.E., J.J. Poos,W.L.T van Densen, and M.A.M. Machiels. In search of a better unit of effort in coastal lift net fishery with lights for small pelagics in Indonesia. Fish. Res., 59: 43-56 (2002).

Pascoe, S., and L. Coglan. Implications of differences in technical efficiency of fishing boats for capacity measurement and reduction. Mar. Policy, 24: 301-307 (2000).

Pascoe, S., J.L. Andersen, and J.W. de Wilde. The impact of management regulation on the technical efficiency of vessels in the Dutch beam trawl fishery. Eur. Rev. Agric. Econ., 28: 187-206 (2001a).

Pascoe, S., L. Coglan, and S. Mardle. Physical versus harvest-based measures of capacity: the case of the United Kingdom vessel capacity unit system. ICES J. Mar. Sci., 58: 1243-1252 (2001b).

Pascoe, S., D. Tingley, and B. Cattermoul. Estimating the efficiency of UK English Channel vessels using DEA and Stochastic Production Frontiers. In: Single output measures of technical efficiency in EU fisheries. (Eds. S. Pascoe, and S. Mardle), CEMARE, University of Portsmouth, UK. CEMARE Report 61, pp. 22-55 (2003).

Poos, J.J., and A.D. Rijnsdorp. An "experiment" on effort allocation of fishing vessels: the role of interference competition and area specialization. Can. J. Fish. Aquat. Sci., 64: 304-313 (2007).

Poos, J. J., J.A. Bogaards, F.J. Quirijns, D.M. Gillis, and A.D. Rijnsdorp. Individual quotas, fishing effort allocation, and over-quota discarding in mixed fisheries. ICES J. Mar. Sci. 67: 323-333 (2010).

Quirijns, F.J., J.J. Poos, and A.D. Rijnsdorp. Standardizing commercial CPUE data in monitoring stock dynamics: Accounting for targeting behaviour in mixed fisheries. Fish. Res., 89: 1-8 (2008).

Rahikainen, M., and S. Kuikka. Fleet dynamics of herring trawlers-change in gear size and implications for interpretation of catch per unit effort. Can. J. Fish. Aquat. Sci., 59: 531-541 (2002).

Reeves, S., P. Marchal, S. Mardle, et al. From fish to fisheries: the changing of focus of management advice. In: Advances in Fisheries Science, 50 years on from Beverton and Holt. (Eds. A. Payne, J. Cotter and T. Potter), Blackwell Publishing Ltd, Oxford, pp. 135-144 (2008).

Reid, D.G., N. Graham, D.J. Rihan, et al. Do big boats tow big nets? ICES J. Mar. Sci., 68: 1663-1669 (2011). 
Rihan, D. Comparison of twin-rig and single-rig trawling in terms of relative fishing efficiency. In: FAO Fisheries Technical Paper, Vol 482. Economic Performance and Fishing Efficiency of Marine Capture Fisheries (Ed. R. Mitchell), pp. 43-51 (2005).

Rijnsdorp, A. D., N. Daan, and W. Dekker. Partial fishing mortality per fishing trip: a useful indicator of effective fishing effort in mixed demersal fisheries. ICES J. Mar. Sci., 63: 556-566 (2006).

Rijnsdorp, A.D., N. Daan, W. Dekker, J.J Poos, and W.L.T. Van Densen. Sustainable use of flatfish resources: addressing the credibility crisis in mixed fisheries management. J. Sea Res., 57: 114-125 (2007).

Rijnsdorp, A.D., J.J. Poos, R. HilleRisLambers, J-W. De Wilde, and W.M. Den Heijer. The arms race between fishers. J. Sea Res.., 60: 126-138 (2008).

Rijnsdorp, A.D., J.J. Poos, and F.J. Quirijns. Spatial dimension and exploitation dynamics of local fishing grounds by fishers targeting several flatfish species. Can. J. Fish. Aquat. Sci., 68: 1064-1076 (2011).

Robins, C. M., Y. Wang, and D. Die. The impact of global positioning systems and plotters on fishing power in the northern prawn fishery, Australia. Can. J. Fish. Aquat. Sci., 55: 1645-1651 (1998).

Rose, G.A., and D.W. Kulka. Hyperaggregation of fish and fisheries: how catch-per-unit-effort increased as the northern cod (Gadus morhua) declined. Can. J. Fish. Aquat. Sci., 56 (Suppl. 1): 118-127 (1999).

Rossiter, T., and S. Stead. Days at sea: from the fishers’ mouth. Mar. Policy, 27: 281-288 (2003).

Sainsbury, J.C. Commercial fishing methods, an introduction to vessels and gears. Fishing News Books, Blackwell Science Ltd, Oxford, 359 pp. (1996).

Salas, S., and D. Gaertner. The behavioural dynamics of fishers: management Implications. Fish Fish., 5: 153167 (2004).

Shepherd, J.G. Fishing effort control: could it work under the common fisheries policy? Fish. Res., 63: 149153 (2003).

Somerton, D.A. Do Pacific cod (Gadus macrocephalus) and walleye pollock (Theragra chalcogramma) lack a herding response to the doors, bridles, and mudclouds of survey trawls? ICES J. Mar. Sci., 61: 11861189 (2004).

Standal, D. Nuts and bolts in fisheries management - a technological approach to sustainable fisheries? Mar. Policy, 29: 255-263 (2005). 
Standal, D. Institutional changes and fleet structure: towards the final solution? Mar. Policy, 31: 94-100 (2007).

Stefansson, G., and A.A. Rosenberg. Combining control measures for more effective management of fisheries under uncertainty: quotas, effort limitation and protected areas. Philos. T. Roy. Soc. B, 360: 133-146 (2005).

Thomsen, B. Efficiency changes in the Faroese pair-trawler fleet. In: FAO Fisheries Technical Paper, Vol 482. Economic Performance and Fishing Efficiency of Marine Capture Fisheries (Ed. R. Mitchell), pp. 3343 (2005).

Tietze, U., Thiele, W., Lasch, R., Thomsen, B., Rihan, D. Economic performance and fishing efficiency of marine capture fisheries. FAO Fisheries Technical Paper No. 482, 68 pp. (2005).

Thorson, J. T. Auxiliary and focal assessment models: a proof-of-concept involving time-varying catchability and fishery stock-status evaluation. ICES J. Mar. Sci., 68: 2264-2276 (2011).

Ulrich, C., Wilson, D.C.K., Nielsen, J.R., Bastardie, F., Reeves, S.A., Andersen, B.S., Eigaard, O.R.. Challenges and opportunities for fleet- and métier-based approaches for fisheries management under the European Common Fishery Policy. Ocean Coast. Manage. 70: 38-47 (2012).

Valdemarsen, J.W. Technological trends in capture fisheries. Ocean Coast. Manage., 44: 635-651 (2001).

Valdemarsen, J.W., and P. Suuronen. Modifying Fishing Gear to Achieve Ecosystem objectives. In: Responsible Fisheries in the Marine Ecosystem (Eds. M. Sinclair and G. Valdimarsson). FAO and CABI Publishing, Rome, pp. 321-341 (2003).

Whitmarsh, D. Technological change and marine fisheries development. Mar. Policy 14: 15-22 (1990). Whitmarsh, D., C.A. Reid, C. Gulvin, M.R. Dunn. Natural Resource Exploitation and the Role of New Technology: a Case-history of the UK Herring Industry. Environ. Conserv., 22: 103-110 (1995).

Wilberg, M.J., J.T. Thorson, B.C. Linton, and J. Berkson. Incorporating Time-Varying Catchability into Population Dynamic Stock Assessment Models. Rev. Fish. Sci., 18: 7-24 (2010).

Wilhelmsson, D., T. Malm, M.C. Öhman. The influence of offshore wind power on demersal fish. ICES J. Mar. Sci., 63: 775-784 (2006). 
Table 1. Suggested improved descriptors of effective effort for 7 main vessel types based on the definition of effort as a function of capacity and activity (Figure 1) and the concept of technological influence on catchability through either, q, density or effort utilisation.

Table 2. Summary of whole-fishery estimates of annual efficiency changes in commercial fisheries. Some of the entries by vessel type are aggregate estimates of two or three separate estimates by species. The estimates represent a variety of methods, models, and outcomes, and are as such not directly comparable, but a crude grouping in technology related estimates and overall estimates (technology, behavioural and regulation related) is made to allow the extraction of average values (arithmetic mean). 


\begin{tabular}{|c|c|c|c|c|c|c|c|c|c|c|c|c|}
\hline \multirow{2}{*}{$\begin{array}{l}\text { Fisheries } \\
\text { type }\end{array}$} & \multicolumn{3}{|c|}{ Characteristics } & \multicolumn{4}{|c|}{ Optimal descriptors } & \multicolumn{3}{|c|}{ Available descriptors } & \multicolumn{2}{|c|}{ Suggested descriptors } \\
\hline & Detection & $\begin{array}{l}\text { Characteristics } \\
\text { of target } \\
\text { species }\end{array}$ & $\begin{array}{l}\text { Main } \\
\text { catchability } \\
\text { factor }\end{array}$ & $\begin{array}{l}\text { Effort } \\
\text { measure }\end{array}$ & $\begin{array}{l}\text { Capacity } \\
\text { measure }\end{array}$ & $\begin{array}{l}\text { Activity } \\
\text { measure }\end{array}$ & $\begin{array}{l}\text { Main short- } \\
\text { comings }\end{array}$ & $\begin{array}{l}\text { logbook Proxy } \\
\text { for capacity }\end{array}$ & $\begin{array}{l}\text { logbook Proxy } \\
\text { for activity }\end{array}$ & $\begin{array}{l}\text { Additional } \\
\text { proxy short- } \\
\text { comings }\end{array}$ & $\begin{array}{l}\text { New logbook } \\
\text { variables }\end{array}$ & $\begin{array}{l}\text { Suggested effort } \\
\text { descriptor }\end{array}$ \\
\hline $\begin{array}{l}\text { Demersal } \\
\text { seiners }\end{array}$ & $\begin{array}{l}\text { "blind } \\
\text { fishing" }\end{array}$ & $\begin{array}{l}\text { Non schooling } \\
\text { herding }\end{array}$ & Gear size & $M^{2}$ fished & $\begin{array}{l}\text { Seine rope } \\
\text { length }\end{array}$ & $\begin{array}{l}\text { Haul } \\
\text { number }\end{array}$ & $\begin{array}{l}\text { q (e.g. ground } \\
\text { gear, seine } \\
\text { design) }\end{array}$ & $\begin{array}{l}\text { Kilowatt, boat } \\
\text { size (Loa, GRT) }\end{array}$ & $\begin{array}{l}\text { Hours of } \\
\text { fishing }\end{array}$ & $\begin{array}{l}\text { Trends in } \\
\text { effort } \\
\text { utilisation }\end{array}$ & $\begin{array}{l}\text { i) Seine rope } \\
\text { length ii) } \\
\text { number of hauls }\end{array}$ & $\begin{array}{l}\text { Loa * } \\
\text { rope-length* } \\
\text { haul number }\end{array}$ \\
\hline $\begin{array}{l}\text { Pelagic/purse } \\
\text { seiners }\end{array}$ & Searching & Schooling & $\begin{array}{l}\text { Sonar range, } \\
\text { Spotter } \\
\text { planes, FADs }\end{array}$ & $\mathrm{M}^{2}$ searched & Sonar range & $\begin{array}{l}\text { Distance } \\
\text { searched }\end{array}$ & $\begin{array}{l}q \text { (e.g. seine } \\
\text { design) }\end{array}$ & $\begin{array}{l}\text { Kilowatt, boat } \\
\text { size (Loa, GRT) }\end{array}$ & $\begin{array}{l}\text { Hours of } \\
\text { fishing }\end{array}$ & None & $\begin{array}{l}\text { i) Sonar range } \\
\text { ii) loading } \\
\text { capacity }\end{array}$ & $\begin{array}{l}\text { Sonar range* loading } \\
\text { capacity* distance } \\
\text { searched }\end{array}$ \\
\hline $\begin{array}{l}\text { Demersal } \\
\text { trawlers }\end{array}$ & $\begin{array}{l}\text { "blind } \\
\text { fishing" }\end{array}$ & $\begin{array}{l}\text { Non schooling } \\
\text { Herding and } \\
\text { non-herding }\end{array}$ & Gear size & $\begin{array}{l}\text { i) } M^{2} \text { fished } \\
\text { ii) } M^{2} \text { fished } \\
\text { iii) } M^{3} \text { fished* }\end{array}$ & $\begin{array}{l}\text { i) door spread } \\
\text { ii) ground gear } \\
\text { length } \\
\text { iii) trawl mouth } \\
\text { area }\end{array}$ & $\begin{array}{l}\text { Distance } \\
\text { trawled }\end{array}$ & $\begin{array}{l}\text { q (e.g. ground } \\
\text { gear, trawl } \\
\text { design) }\end{array}$ & $\begin{array}{l}\text { Kilowatt, boat } \\
\text { size (Loa, GRT) }\end{array}$ & $\begin{array}{l}\text { Hours of } \\
\text { fishing }\end{array}$ & $\begin{array}{l}\text { Trends in } \\
\text { effort } \\
\text { utilisation }\end{array}$ & $\begin{array}{l}\text { i) Door spread/ } \\
\text { ground gear } \\
\text { length/trawl } \\
\text { mouth area } \\
\text { ii) trawling } \\
\text { speed } \\
\text { iii) trawling time }\end{array}$ & $\begin{array}{l}\text { Loa* } \\
\text { Door spread/ ground } \\
\text { gear length/trawl } \\
\text { mouth area * } \\
\text { trawled distance }\end{array}$ \\
\hline $\begin{array}{l}\text { Pelagic } \\
\text { trawlers }\end{array}$ & Searching & schooling & Sonar range & $\mathrm{M}^{2}$ searched & Sonar range & $\begin{array}{l}\text { Distance } \\
\text { searched }\end{array}$ & $\begin{array}{l}\text { q (e.g. trawl } \\
\text { design) }\end{array}$ & $\begin{array}{l}\text { Kilowatt, boat } \\
\text { size (Loa, GRT) }\end{array}$ & $\begin{array}{l}\text { Hours of } \\
\text { fishing }\end{array}$ & None & $\begin{array}{l}\text { i) Sonar range } \\
\text { ii) loading } \\
\text { capacity }\end{array}$ & $\begin{array}{l}\text { Sonar range* loading } \\
\text { capacity* distance } \\
\text { searched }\end{array}$ \\
\hline $\begin{array}{l}\text { Beam } \\
\text { trawlers }\end{array}$ & $\begin{array}{l}\text { "blind } \\
\text { fishing" }\end{array}$ & Non schooling & Gear size & $M^{2}$ fished & $\begin{array}{l}\text { Total beam } \\
\text { width }\end{array}$ & $\begin{array}{l}\text { Distance } \\
\text { trawled }\end{array}$ & $\begin{array}{l}\text { q (e.g. } \\
\text { ticklers, } \\
\text { schafers) }\end{array}$ & $\begin{array}{l}\text { Kilowatt, boat } \\
\text { size (Loa, GRT) }\end{array}$ & $\begin{array}{l}\text { Hours of } \\
\text { fishing }\end{array}$ & $\begin{array}{l}\text { Trends in } \\
\text { effort } \\
\text { utilisation }\end{array}$ & $\begin{array}{l}\text { i) Trawling } \\
\text { speed } \\
\text { ii) Trawling } \\
\text { time }\end{array}$ & $\begin{array}{l}\text { Loa* } \\
\text { Beam width* trawled } \\
\text { distance }\end{array}$ \\
\hline Gill netters & $\begin{array}{l}\text { "blind } \\
\text { fishing" }\end{array}$ & $\begin{array}{l}\text { Active } \\
\text { swimming }\end{array}$ & Gear size & $M^{1}$ fished & $\begin{array}{l}\text { Length of nets } \\
\text { set }\end{array}$ & $\begin{array}{l}\text { Number of } \\
\text { sets }\end{array}$ & $\begin{array}{l}\text { q (e.g. net- } \\
\text { ting material, } \\
\text { diameter) }\end{array}$ & $\begin{array}{l}\text { Kilowatt, boat } \\
\text { size (Loa, GRT) }\end{array}$ & $\begin{array}{l}\text { Hours of } \\
\text { fishing }\end{array}$ & $\begin{array}{l}\text { Trends in } \\
\text { effort } \\
\text { utilisation }\end{array}$ & $\begin{array}{l}\text { i) Meters of net } \\
\text { set } \\
\text { ii) sets per trip }\end{array}$ & $\begin{array}{l}\text { Loa* } \\
\text { Length of nets* } \\
\text { number of sets }\end{array}$ \\
\hline Long liners & $\begin{array}{l}\text { "blind } \\
\text { fishing" }\end{array}$ & Predatory & Gear size & Hooks fished & $\begin{array}{l}\text { number of } \\
\text { hooks set }\end{array}$ & $\begin{array}{l}\text { Number of } \\
\text { sets }\end{array}$ & $\begin{array}{l}\text { q (e.g. hook } \\
\text { design, bait } \\
\text { used) }\end{array}$ & $\begin{array}{l}\text { Kilowatt, boat } \\
\text { size (Loa, GRT) }\end{array}$ & $\begin{array}{l}\text { Hours of } \\
\text { fishing }\end{array}$ & $\begin{array}{l}\text { Trends in } \\
\text { effort } \\
\text { utilisation }\end{array}$ & $\begin{array}{l}\text { i) Hooks per set } \\
\text { ii) sets per trip }\end{array}$ & $\begin{array}{l}\text { Loa*Number of } \\
\text { hooks*number of } \\
\text { sets }\end{array}$ \\
\hline
\end{tabular}

* In some demersal trawl fisheries trawl height is an important component of gear efficiency, e.g. Sand eel fishery and northern shrimp fishery 


\begin{tabular}{|c|c|c|c|c|c|c|c|}
\hline Vessel type & Reference & Outcome & Methodology & Case study & Time period & Tech-related change (\%) & Overall change (\%) \\
\hline Otter trawlers & Banks et al., 2002 & Technical efficiency & Econometric & DK-Baltic cod & $1987-1999$ & 1.8 & 0 \\
\hline Otter trawlers & Braccini et al. 2012 & Fishing power & GLMM & AU-Queensland eastern prawn & 1988-2004 & 0.7 & 2.3 \\
\hline Otter trawlers & Kirkley et al., 2004 & Technical efficiency & Econometric & F-Séte Mediterranean trawlers & 1985-1999 & 1 & -3.0 \\
\hline Otter trawlers & Marchal et al. 2001 & Fishing Power & GLM & DK-Baltic Sea cod & 1987-1999 & & 2.0 \\
\hline Otter trawlers & Marchal et al. 2002 & Fishing power & GLM & DK-North Sea demersal 0-300HP & $1987-1998$ & & 0 \\
\hline Otter trawlers & Marchal et al. 2002 & Fishing power & GLM & DK-North Sea demersal > 300HP & $1987-1998$ & & 8.0 \\
\hline Otter trawlers & Marchal et al. 2002 & Fishing power & GLM & NO- North Sea demersal 0-1000HP & $1980-1998$ & & 6.8 \\
\hline Otter trawlers & Marchal et al. 2002 & Fishing power & GLM & NO-North Sea demersal 1000-2000HP & 1980-1998 & & 6.8 \\
\hline Otter trawlers & Marchal et al. 2002 & Fishing power & GLM & NO-North Sea demersal 2000-3000HP & 1980-1998 & & 2.0 \\
\hline Otter trawlers & O’Neill et al. 2007 & Fishing power & GLMM & AU-Queensland northern prawn & $1988-2004$ & 0.3 & 0.4 \\
\hline Otter trawlers & O’Neill et al. 2007 & Fishing power & GLMM & AU-Queensland endeavour prawn & $1988-2004$ & 1.7 & 0.4 \\
\hline Otter trawlers & O’Neill et al. 2007 & Fishing power & GLMM & AU-Queensland southern prawn & $1988-2004$ & 0.9 & 0.7 \\
\hline Otter trawlers & O'Neill et al. 2007 & Fishing power & GLMM & AU-Queensland red spot prawn & $1988-2004$ & 0.5 & 1.1 \\
\hline Otter trawlers & O’Neill et al. 2007 & Fishing power & GLMM & AU-Queensland eastern prawn & 1988-2004 & 1 & 2.9 \\
\hline Otter trawlers & O'Neill et al. 2007 & Fishing power & GLMM & AU-Queensland - Saucer scallop & $1988-2004$ & 0.7 & 1.0 \\
\hline Otter trawlers & Bjørndal et al. 2003 & Technical efficiency & Econometric & UK-North Sea & $1990-2000$ & & 2.6 \\
\hline Otter trawlers & Pascoe et al. 2003 & Technical efficiency & Econometric & UK-Channel & 1993-1998 & & 4.8 \\
\hline Otter trawlers & Hutton et al. 2003 & Technical efficiency & Econometric & UK-North Sea cod, haddock, saithe & $1990-2000$ & & 0.5 \\
\hline Otter trawlers & Hutton et al. 2003 & Technical efficiency & Econometric & UK-North Sea Nephrops & $1990-2000$ & & 6.2 \\
\hline Average & & & & & & 1.0 & 2.4 \\
\hline Beam trawlers & Banks et al., 2002 & Technical efficiency & Econometric & NL-North Sea & 1983-1998 & & 0.8 \\
\hline Beam trawlers & Marchal et al. 2002 & $\begin{array}{l}\text { Fishing power } \\
\text { lat }\end{array}$ & GLM & UK-North Sea & 1989-1998 & & -2.1 \\
\hline Beam trawlers & Marchal et al. 2002 & Fishing power & GLM & NL- North Sea 0-300HP & 1991-1998 & & 3.0 \\
\hline Beam trawlers & Marchal et al. 2002 & Fishing power & GLM & NL- North Sea > 300HP & 1991-1998 & & 4.7 \\
\hline Beam trawlers & Rijnsdorp 2006 & Partial F & GLM & NL-North Sea & $1990-2003$ & 2.0 & 2.2 \\
\hline $\begin{array}{l}\text { Beam trawlers } \\
\text { Beam }\end{array}$ & Bjørndal et al. 2003 & Technical efficiency & Econometric & UK-North Sea & $1990-2000$ & & -1.0 \\
\hline Beam trawlers & Pascoe et al. 2003 & Technical efficiency & Econometric & UK- Channel & 1993-1998 & & 0 \\
\hline Beam trawlers & Hutton et al. 2003 & Technical efficiency & Econometric & UK- North Sea & $1990-2000$ & & 0 \\
\hline Average & & & & & & 2.0 & 1.0 \\
\hline Gill netters & Marchal et al. 2001 & Fishing Power & GLM & DK-Baltic cod & 1987-1999 & & 6.0 \\
\hline Gill netters & Marchal et al. 2002 & Fishing power & GLM & DK-North Sea & $1987-1998$ & & 9.5 \\
\hline Gill netters & Marchal et al. 2002 & Fishing power & GLM & UK-North Sea & 1989-1998 & & -4.4 \\
\hline Gill netters & Marchal et al. 2002 & Fishing power & GLM & NO-North Sea & 1980-1998 & & 4.0 \\
\hline Gill netters & Hutton et al. 2003 & Technical efficiency & Econometric & UK- North Sea & $1990-2000$ & & 0 \\
\hline Average & & & & & & & 3.0 \\
\hline $\begin{array}{l}\text { Scallop dredgers } \\
\text { Average }\end{array}$ & Pascoe et al. 2003 & Technical efficiency & Econometric & UK- Channel & 1993-1998 & & $\begin{array}{l}-3.6 \\
-3.6\end{array}$ \\
\hline Demersal seiners & Marchal et al. 2002 & Fishing power & GLM & DK-North Sea & 1987-1998 & & 11.0 \\
\hline Demersal seiners & Hutton et al. 2003 & Technical efficiency & Econometric & UK- North Sea & $1990-2000$ & & -14.5 \\
\hline Average & & & & & & & -1.8 \\
\hline Long liners & Marchal et al. 2002 & Fishing power & GLM & NO-North demersal & 1980-1998 & & 16.5 \\
\hline Long liners & Hutton et al. 2003 & Technical efficiency & Econometric & UK- North Sea & $1990-2000$ & & -2.4 \\
\hline Long liners & Eigaard et al. 2011 & Catchability & GLM & Faroe Islands Cod & $1986-2002$ & 4.3 & \\
\hline Long liners & Eigaard et al. 2011 & Catchability & GLM & Faroe Islands Haddock & $1986-2002$ & 9.0 & \\
\hline Average & & & & & & 6.7 & 7.1 \\
\hline Potters & Pascoe et al. 2003 & Technical efficiency & Econometric & UK- Channel & 1993-1998 & & 3.6 \\
\hline Potters & Hutton et al. 2003 & Technical efficiency & Econometric & UK- North Sea & $1990-2000$ & & 2.4 \\
\hline Average & & & & & & & 3.0 \\
\hline \multicolumn{6}{|c|}{ Average across vessel types } & 3.2 & 1.6 \\
\hline
\end{tabular}


Figure 1. The main components and mechanisms of the fisheries and management system as perceived and treated in this study. The non-measurable capacity input to the fisheries system (technological development [highlighted in a darker grey]) and its influence on vessel and fleet fishing mortality is the component in focus in this study.

Figure 2. Fraction of beam trawlers in the Dutch demersal fleet (solid dots) and the average horsepower of the vessels (stars) from 1946 to 2004 (adapted from Rijnsdorp et al., 2008).

Figure 3. Uptake of GPS navigation equipment by vessel size groups (A, B, C) in the Danish otter trawler fleet. Observations are from an official national equipment database covering 12\% of all Danish vessels actively fishing between 1981 and 2002 (Eigaard, 2009).

Figure 4. Uptake of sonar in the Danish otter trawler (stars) and gill netter (dots) fleet by vessel size groups (A, B, C). Observations are from an official equipment database covering $\sim 12 \%$ of all Danish vessels actively fishing between 1981 and 2002.

Figure 5. The incentives (A) and areas (B) of technological investment as informed in skipper interviews with a 10\% sample of the Danish trawler and gill netter fleet in 2005.

Figure 6. Illustration of how technological development on board Danish seiners has led to a substantial change in the effort utilisation at sea and consequently in catch efficiency, from 1975 to 2003.

Figure 7. The development of nominal capacity ( $\mathrm{kW}$ installed engine power) of European fishing fleets since 1992 (solid line). The estimated effective harvest capacity of the EU 12 fleet under the assumption of an annual 3\% efficiency increase in the form of a linear projection of technological creep is shown with a dashed line. (Modified from figure 3 (EC, 2008), page 4). 
Figure 8. Annual variations in an index of fishing power derived from a GLM analysis of partial fishing mortality and applied to 11 North Sea fleets targeting demersal species (Marchal et al., 2002). The error bars are 95\% confidence intervals. In the multi-panel figure the rows are the fleets; (A, B, C) Danish gill-netters, (D, E) Danish otter-trawlers, (F, G, H) English beam-trawlers, (I, J, K) Dutch beam-trawlers, and the rows are the target species; (A, D, F, I) cod, (B, E, G, J) plaice and, (C, H, K) sole in the North Sea. (Modified from figure 8 (Marchal et al., 2002) page 619).

Figure 9. The technologically induced development in fishing power of six Australian trawler fleets relative to 1989. The fixed terms trajectories (dotted lines) represent the fishing power change resulting from technological vessel development (temporal technological development) and the solid lines represent the overall change from both temporal and structural (vessel renewal in the fleets) technological development. Error bars represent 95\% confidence intervals. (Modified from figure 2 (O’Neill and Leigh, 2007) page 90).

Figure 10. Individual (A, B and C) and combined (D) dissemination patterns of five trawler and five gill netter technologies in three Danish vessel groups from 1980 to 2005. The figure is based on data from 27 gill netters, 31 trawlers less than 18m, and 32 trawlers of at least $18 \mathrm{~m}$, interviewed about their history of technological acquirements in the TECTAC project (Marchal, 2006). This sample size corresponds to about $10 \%$ of the total fleet. 
Figure 1

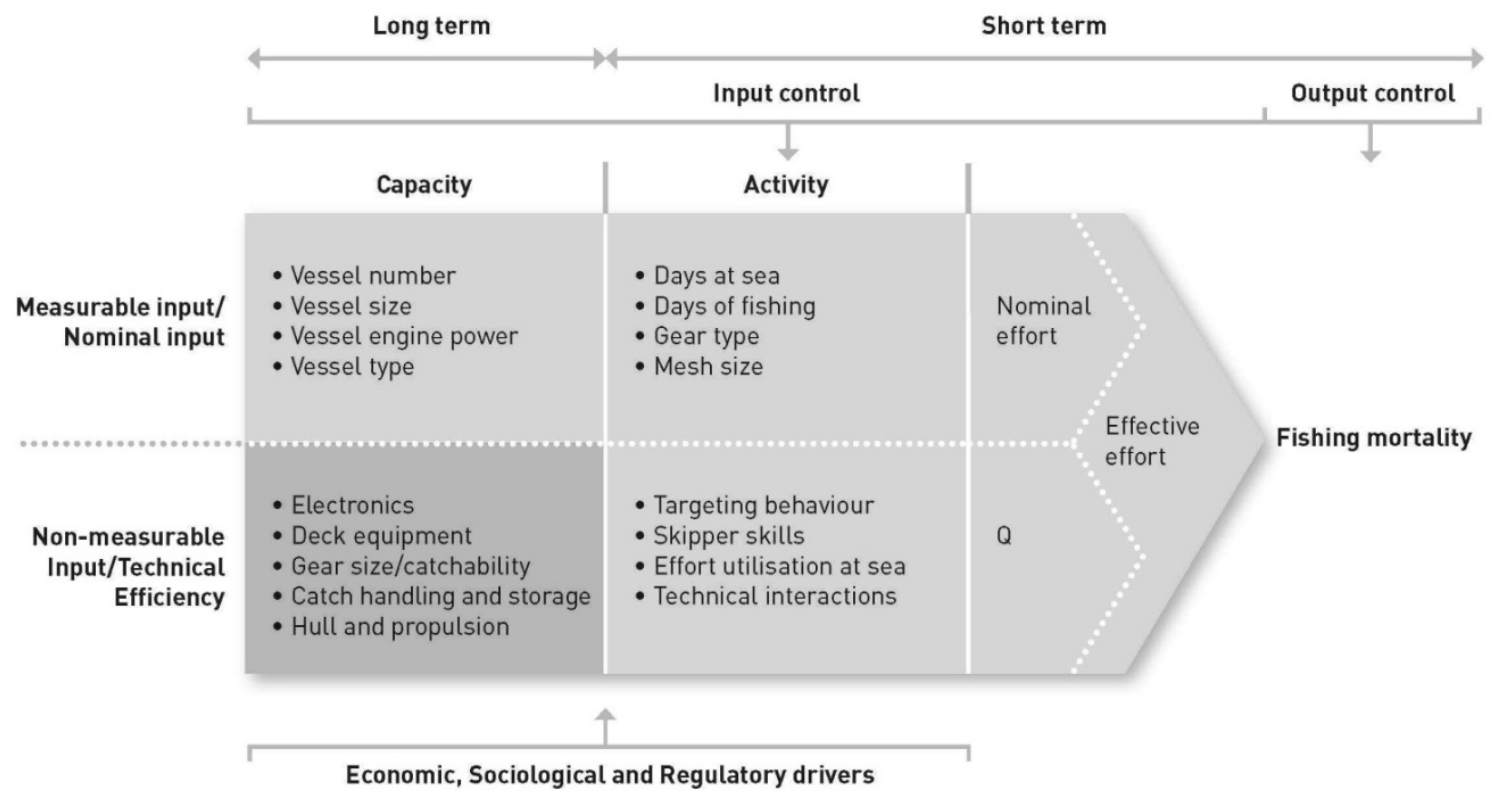


Figure 2

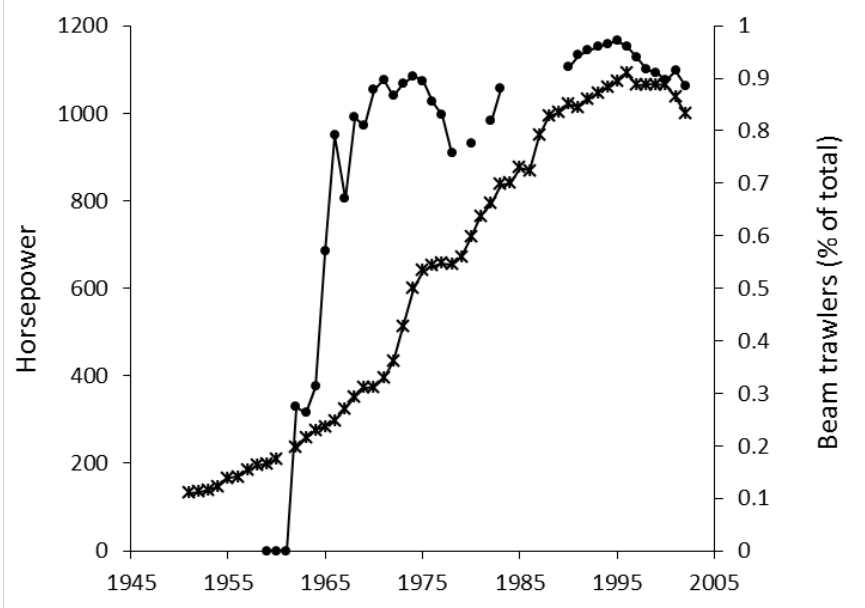


Figure 3
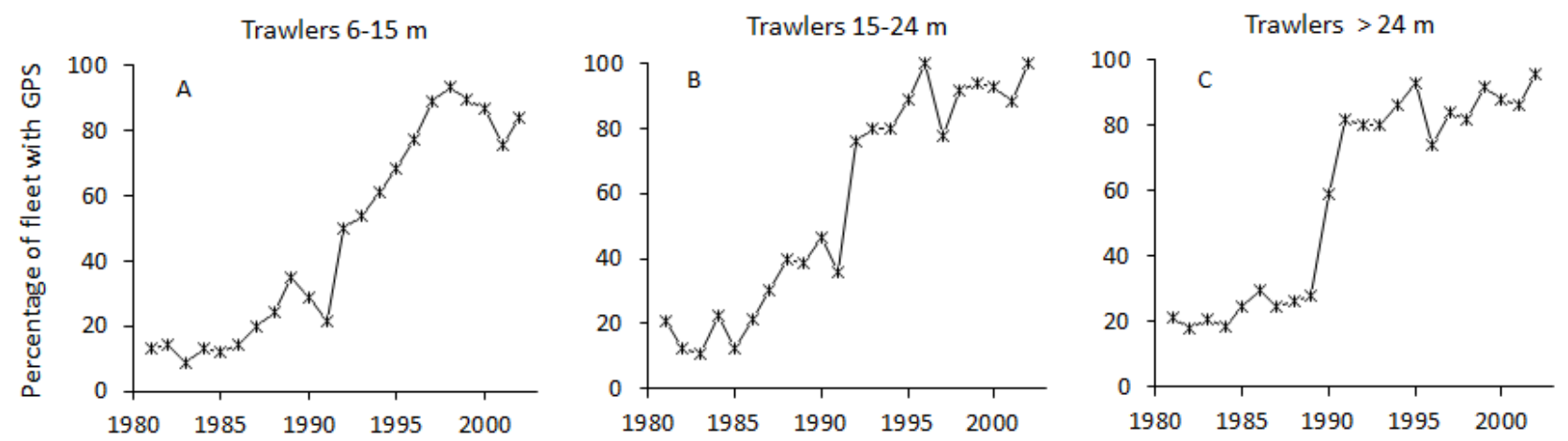
Figure 4

Vessels $<15 \mathrm{~m}$

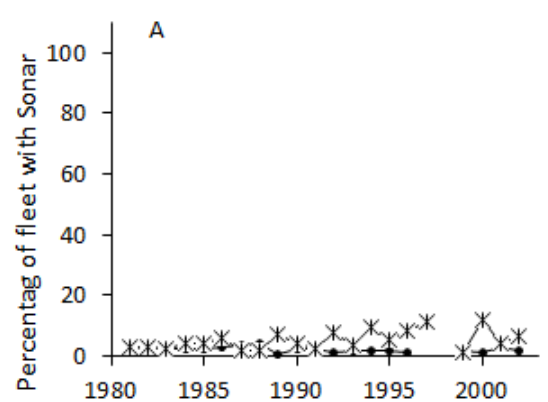

Vessels 15-24 m

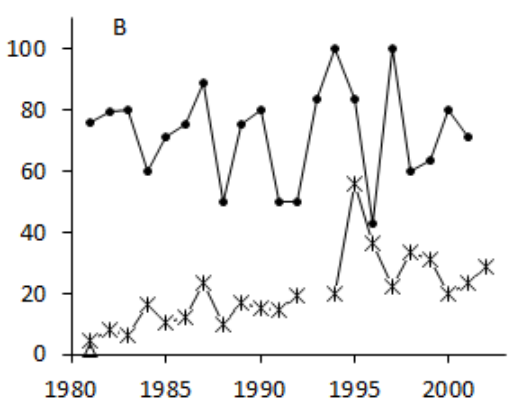

Vessels $>24 m$

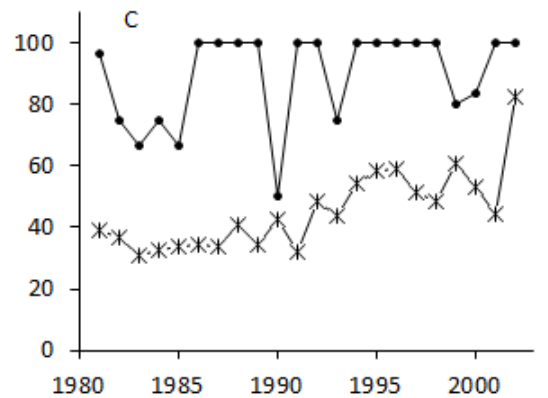


Figure 5
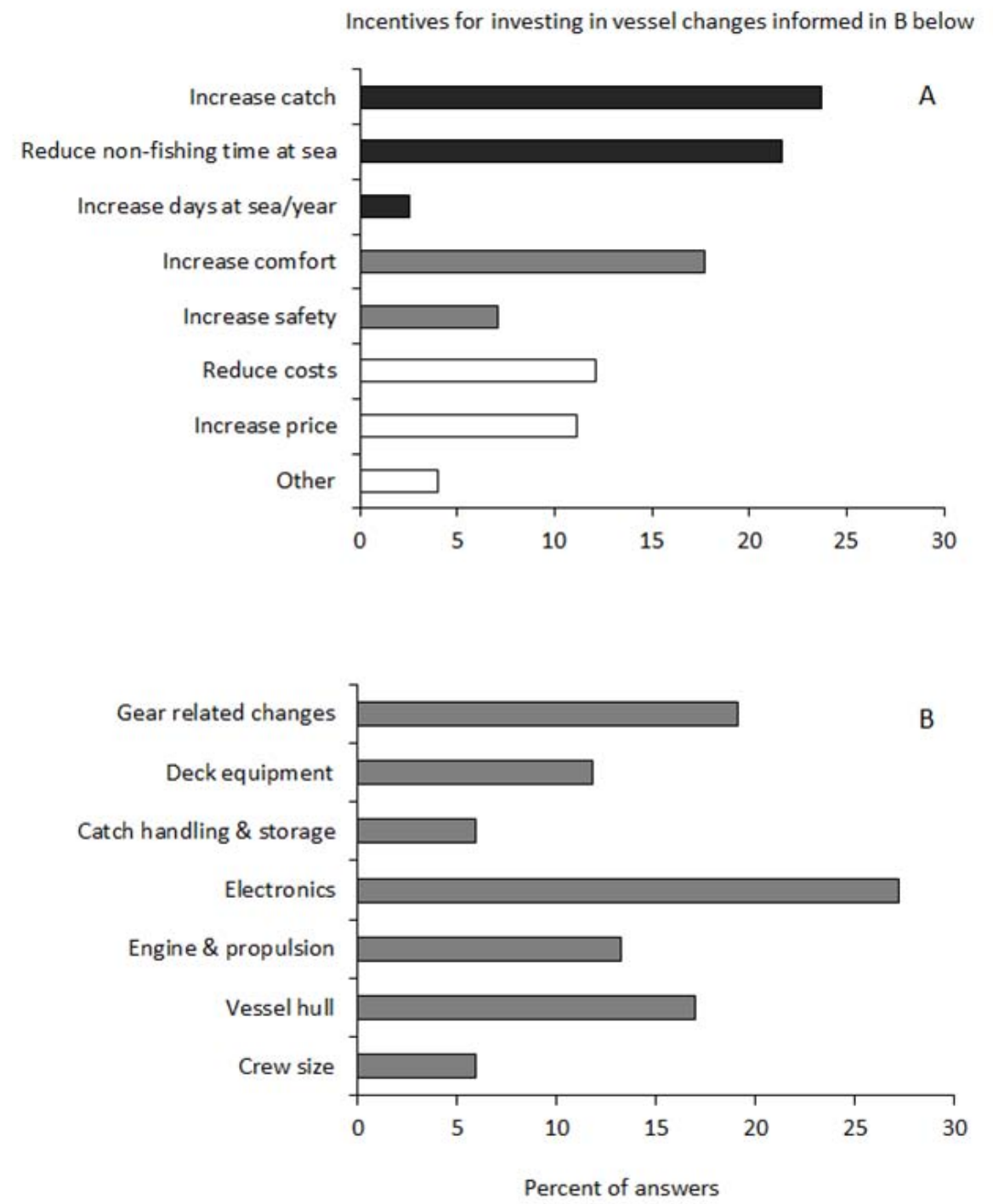
Figure 6

Danish seine fishing day 1975

Haul 1

Haul 2

Haul 3

Haul 4

Fishing / non-fishing time $\approx 1$

Danish seine fishing day 2003

Haul 1

Haul 2

Haul 3

Haul 4

Haul 5

Fishing / non-fishing time $\approx 2$ 
Figure 7

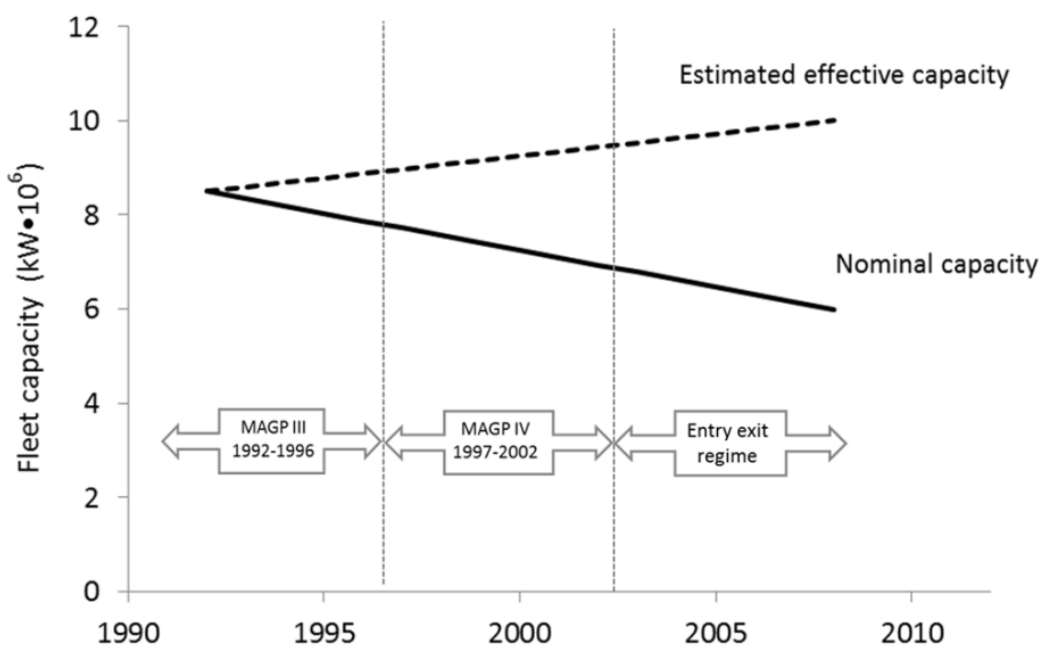


Figure 8

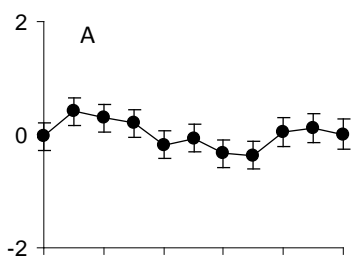

198819901992199419961998

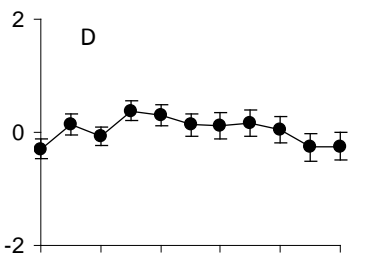

198819901992199419961998

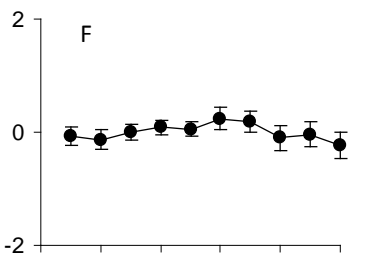

198819901992199419961998

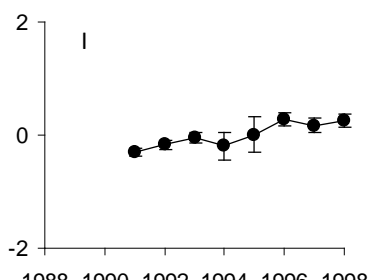

198819901992199419961998
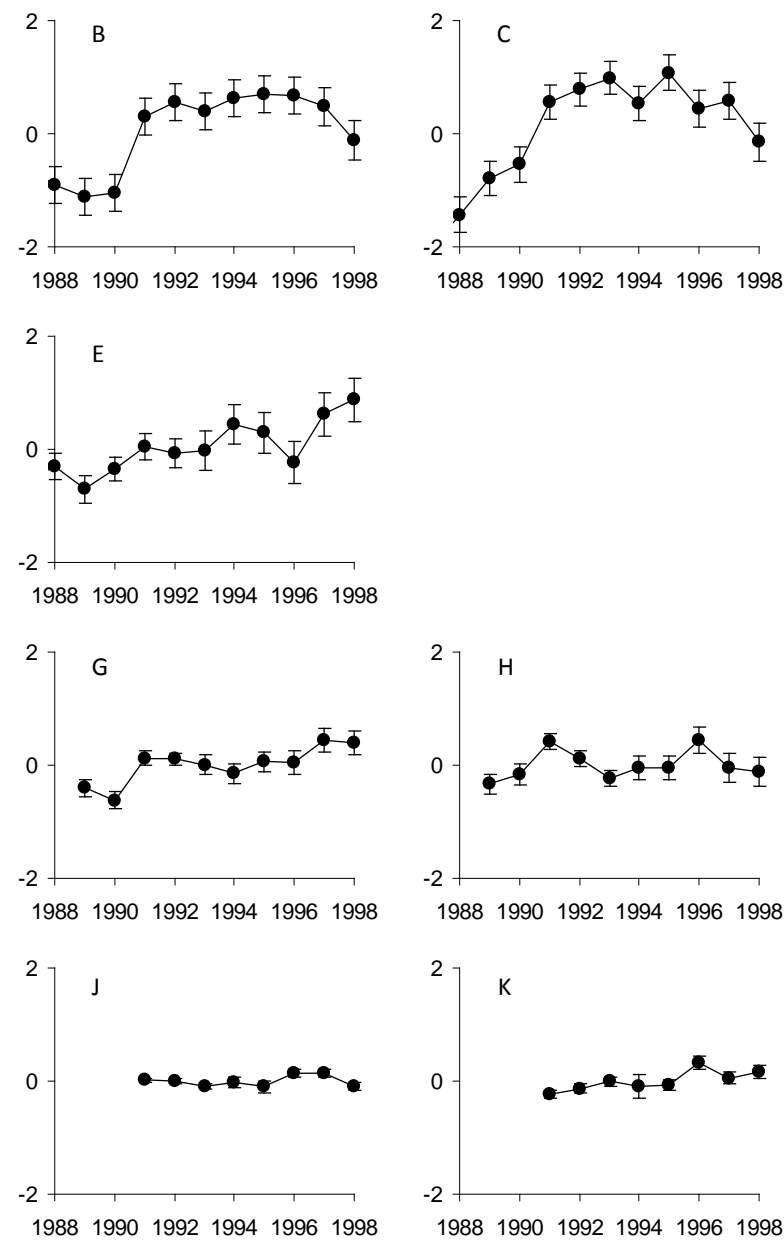
Figure 9
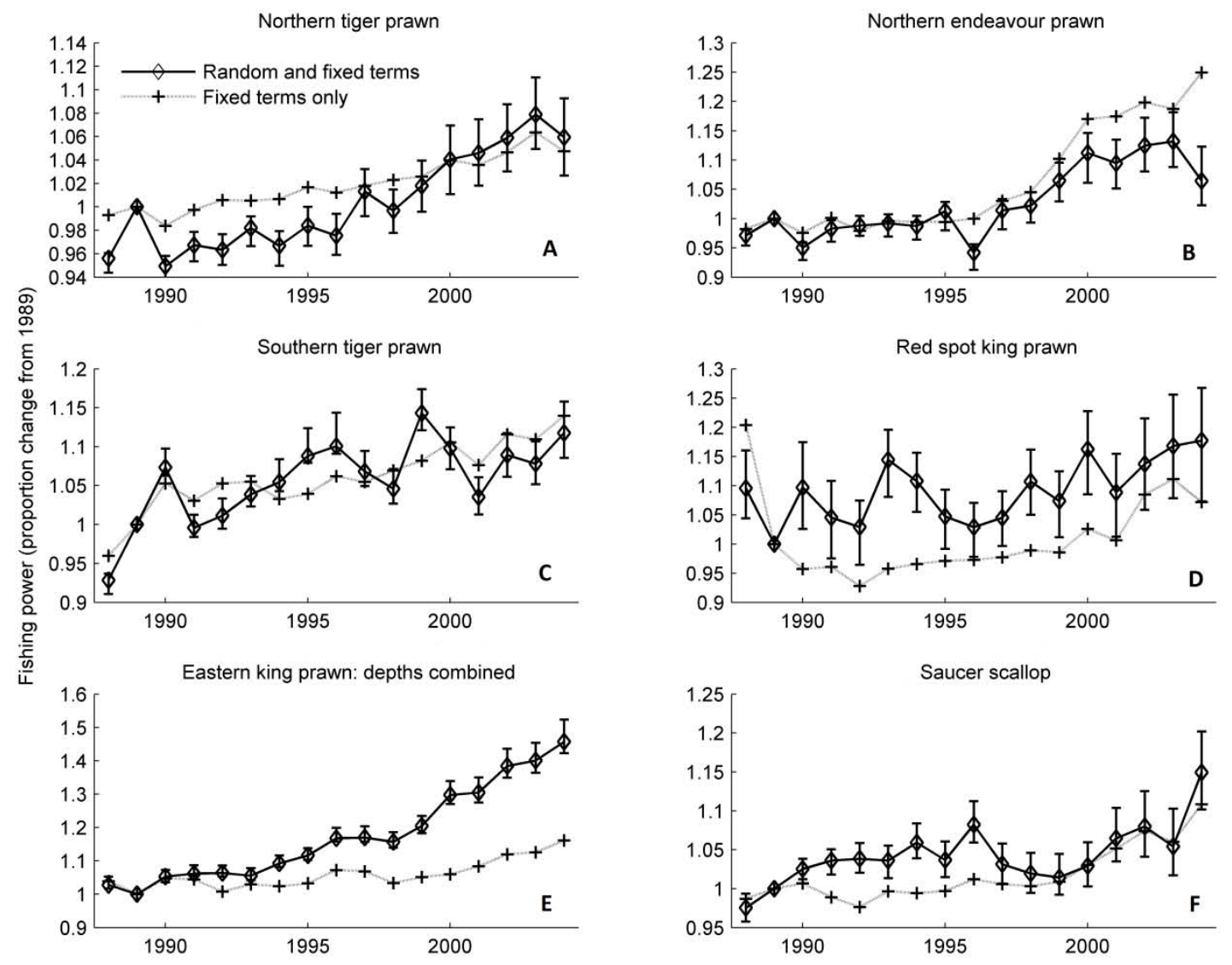
Figure 10
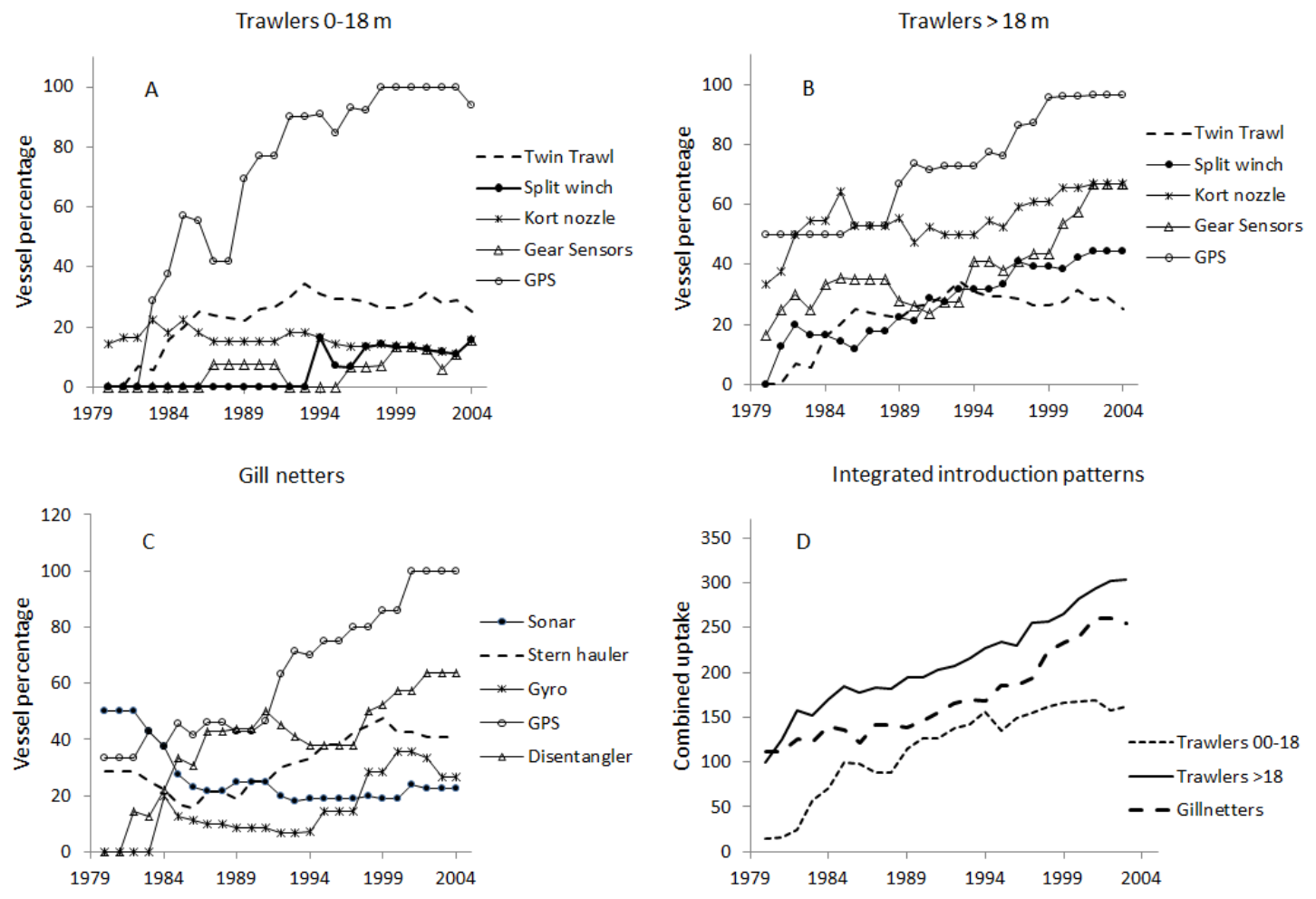